\title{
Morphological and Molecular Perspectives on the Phylogeny, Evolution, and Classification of Weevils (Coleoptera: Curculionoidea): Proceedings from the 2016 International Weevil Meeting
}

Duane D. McKenna 1,* (D), Dave J. Clarke 1, Robert Anderson ${ }^{2}$, Jonas J. Astrin ${ }^{3}$ (D), Samuel Brown ${ }^{4}$ (D), Lourdes Chamorro ${ }^{5}$, Steven R. Davis ${ }^{6}$, Bruno de Medeiros ${ }^{7}$ (i), M. Guadalupe del Rio ${ }^{8}$ (D), Julien Haran ${ }^{9}$ (D), Guillermo Kuschel ${ }^{\dagger}$, Nico Franz 10 (D), Bjarte Jordal ${ }^{11}$, Analia Lanteri ${ }^{8}$, Richard A. B. Leschen ${ }^{12}$, Harald Letsch ${ }^{13}$, Chris Lyal ${ }^{14}$ (iD, Adriana Marvaldi ${ }^{8}$, Jose Ricardo Mermudes ${ }^{15}$ (D), Rolf G. Oberprieler ${ }^{16}$, André Schütte ${ }^{3}$, Andrea Sequeira ${ }^{17}$, Seunggwan Shin ${ }^{1}$, Matthew H. Van Dam ${ }^{18}$ and Guanyang Zhang ${ }^{19}$

1 Department of Biological Sciences, University of Memphis, 3700 Walker Avenue, Memphis, TN 38152, USA; dclarke@fieldmuseum.org (D.J.C.), sshin@memphis.edu (S.S.)

2 Research and Collection Division, Canadian Museum of Nature, P.O. Box 3443, Station D, Ottawa, ON K1P 6P4, Canada; randerson@nature.ca

3 Zoologisches Forschungsmuseum Alexander Koenig, Adenauerallee 160, Bonn 53113, Germany; J.Astrin.ZFMK@uni-bonn.de (J.J.A.), schuette@uni-bonn.de (ZFMK) (A.S.)

4 Bio-Protection Research Centre, P.O. Box 85084, Lincoln University, Lincoln 7647, New Zealand; xsdjbx@gmail.com

5 Systematic Entomology Laboratory, Agricultural Research Service, U.S. Department of Agriculture, c/o National Museum of Natural History, Smithsonian Institution, P.O. Box 37012, MRC-168, Washington, DC 20013-7012, USA; lourdes.chamorro@ars.usda.gov

6 Division of Invertebrate Zoology, American Museum of Natural History, Central Park West at 79th Street, New York, NY 10024, USA; sdavis@amnh.org

7 Museum of Comparative Zoology, Department of Organismic \& Evolutionary Biology, Harvard University, 26 Oxford Street, Cambridge, MA 02138, USA; souzademedeiros@fas.harvard.edu

8 División Entomología, Facultad de Ciencias Naturales y Museo, Universidad Nacional de La Plata, CONICET, Paseo del Bosque s/n, La Plata, Buenos Aires B1900FWA, Argentina; gdelrio@fcnym.unlp.edu.ar (M.G.d.R.); alanteri@fcnym.unlp.edu.ar (A.L.); marvaldi@fcnym.unlp.edu.ar (A.M.)

9 CIRAD, CBGP, Montpellier, France/CBGP, CIRAD, INRA, IRD, Montpellier SupAgro, University Montpellier, 34000 Montpellier, France; julien.haran@cirad.fr

10 School of Life Sciences, Arizona State University, P.O. Box 874501, Tempe, AZ 85287-4501, USA; nico.franz@asu.edu

11 Natural History Museum, The University Museum, University of Bergen, NO-5007 Bergen, Norway; Bjarte.Jordal@uib.no

12 Manaaki Whenua, New Zealand Arthropod Collection, Private Bag 92170, Auckland 1142, New Zealand; leschenr@landcareresearch.co.nz

13 Department für Botanik und Biodiversitätsforschung, Universität Wien, Rennweg 14, 1030 Wien, Austria; harald.letsch@univie.ac.at

14 Department of Entomology, The Natural History Museum, Cromwell Road, London SW 7 5BD, UK; C.lyal@nhm.ac.uk

15 Laboratório de Entomologia, Departamento de Zoologia, Instituto de Biologia, Universidade Federal do Rio de Janeiro, A1-107, Bloco A, Av. Carlos Chagas Filho, 373, Cidade Universitária, Ilha do Fundão, Rio de Janeiro A1-107, Brazil; jrmermudes@gmail.com

16 CSIRO, Australian National Insect Collection, GPO Box 1700, Canberra, ACT 2601, Australia; Rolf.Oberprieler@csiro.au

17 Department of Biological Sciences, Wellesley College, 106 Central Street Wellesley, MA 02481, USA; asequeir@wellesley.edu 
18 Entomology Department, California Academy of Sciences, 55 Music Concourse Drive,

San Francisco, CA 94118, USA, matthewhvandam@gmail.com

19 Florida Museum of Natural History, University of Florida, 1659 Museum Road, P.O. Box 117800,

Gainesville, FL 32611, USA; gyz151@gmail.com

* Correspondence: dmckenna@memphis.edu; Tel.: +1-901-678-1386

+ Deceased.

Received: 30 June 2018; Accepted: 5 July 2018; Published: 18 July 2018

Abstract: The 2016 International Weevil Meeting was held immediately after the International Congress of Entomology (ICE). It built on the topics and content of the 2016 ICE weevil symposium Phylogeny and Evolution of Weevils (Coleoptera: Curculionoidea): A Symposium in Honor of Dr. Guillermo "Willy" Kuschel. Beyond catalyzing research and collaboration, the meeting was intended to serve as a forum for identifying priorities and goals for those who study weevils. The meeting consisted of 46 invited and contributed lectures, discussion sessions and introductory remarks presented by 23 speakers along with eight contributed research posters. These were organized into three convened sessions, each lasting one day: (1) weevil morphology; (2) weevil fossils, biogeography and host/habitat associations; and (3) molecular phylogenetics and classification of weevils. Some of the topics covered included the $1 \mathrm{~K}$ Weevils Project, major morphological character systems of adult and larval weevils, weevil morphological terminology, prospects for future morphological character discovery, phylogenetic analysis of morphological character data, the current status of weevil molecular phylogenetics and evolution, resources available for phylogenetic and comparative genomic studies of weevils, the weevil fossil record, weevil biogeography and evolution, weevil host plants, evolutionary development of the weevil rostrum, resources available for weevil identification and the current status of and challenges in weevil classification.

Keywords: 1K Weevils Project; biogeography; classification; Curculionidae; Curculionoidea; fossils; Guillermo Kuschel; morphology; molecular phylogenetics; DNA barcoding; phylogeny; phytophagy; weevils

\section{Introduction}

The 2016 International Weevil Meeting was held from 1 to 3 October 2016 at the Rosen Centre Hotel (Orlando, FL, U.S.A.) immediately after the International Congress of Entomology (ICE). It built on the topics and content of the 2016 ICE weevil symposium Phylogeny and Evolution of Weevils (Coleoptera: Curculionoidea): A Symposium in Honor of Dr. Guillermo "Willy" Kuschel (Figure 1). The meeting was convened by researchers from the $1 \mathrm{~K}$ Weevils Project (funded by the U.S. National Science Foundation; Figure 2) but was open to attendance by all interested parties. Thirty-two people attended representing 13 countries on five continents (Figure 3; Table 1). Beyond catalyzing research and collaboration, the meeting was intended to serve as a forum for identifying priorities and goals for those who study weevils or otherwise have an interest in them. The meeting consisted of 46 invited and contributed lectures, pre-arranged discussion sessions and introductory remarks presented by 23 speakers along with eight contributed research posters (three of these are summarized herein). These were organized into three convened sessions, each lasting one day: (1) weevil morphology; (2) weevil fossils, biogeography and host/habitat associations; and (3) molecular phylogenetics and classification of weevils. At the close of the meeting, the attendees discussed ideas for future research and presented a leather-bound journal for Dr. Kuschel (delivered to him after the meeting by Samuel Brown) with their personal notes and thanks in recognition of his friendship, collaboration and many important contributions to the study of weevils and beyond. This paper reports on the meeting, including a summary of the scientific content presented. 


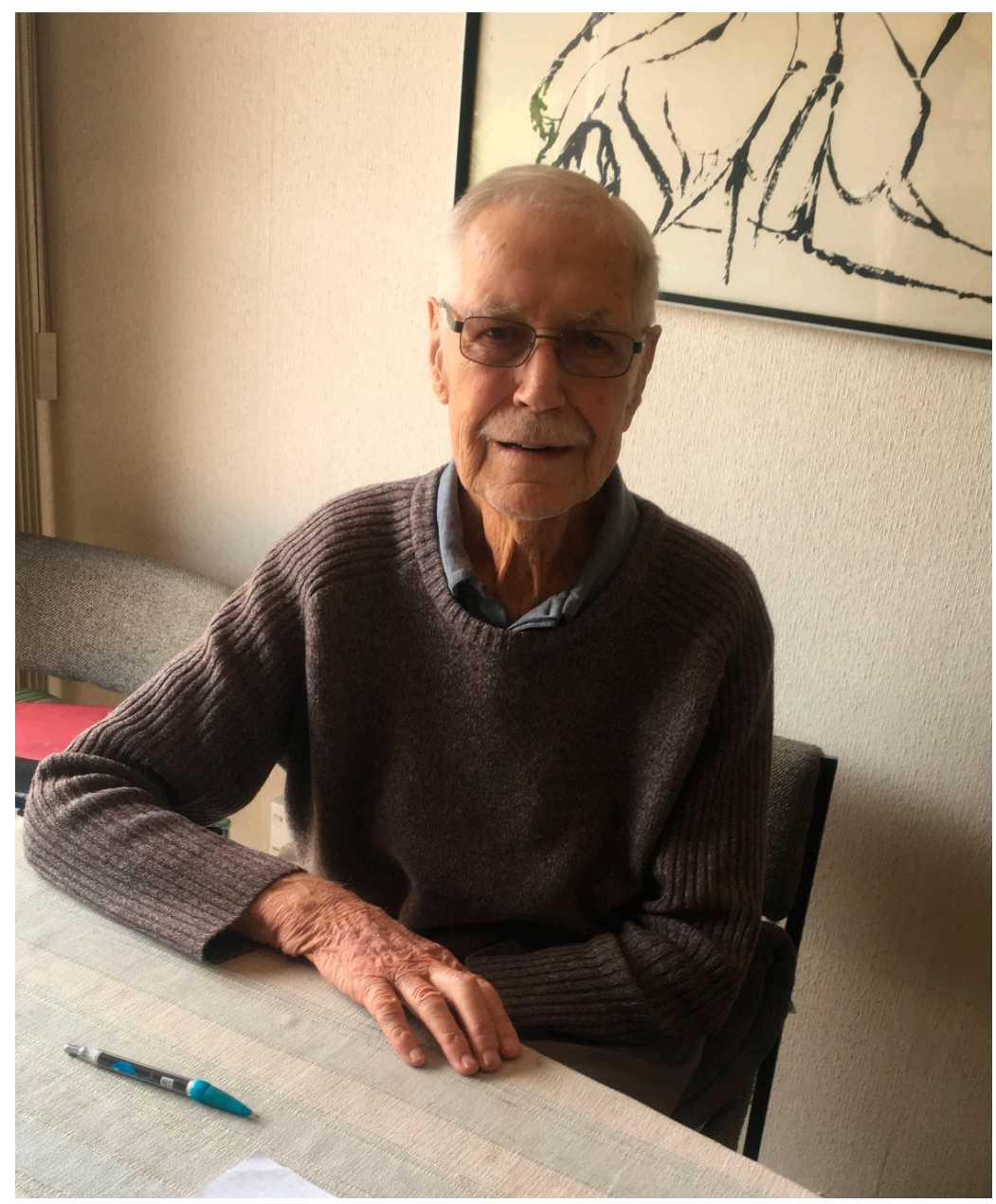

Figure 1. Guillermo "Willy" Kuschel at his home in Lynnfield, AK, New Zealand (5 January 2017). Courtesy, D. Clarke.
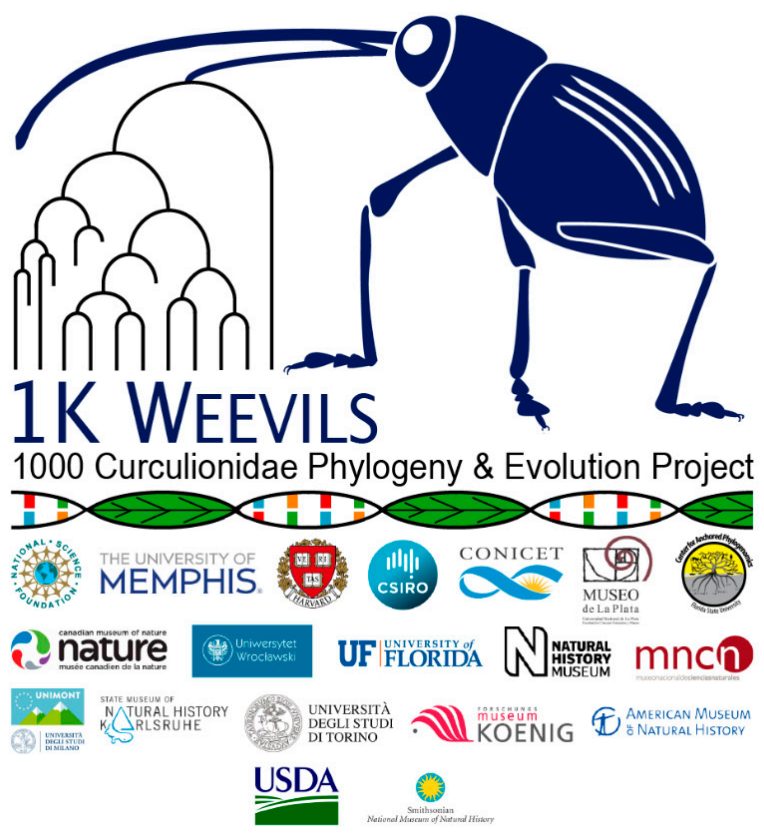

Figure 2. 1000 Curculionidae Phylogeny and Evolution Project (1K Weevils) logo. 


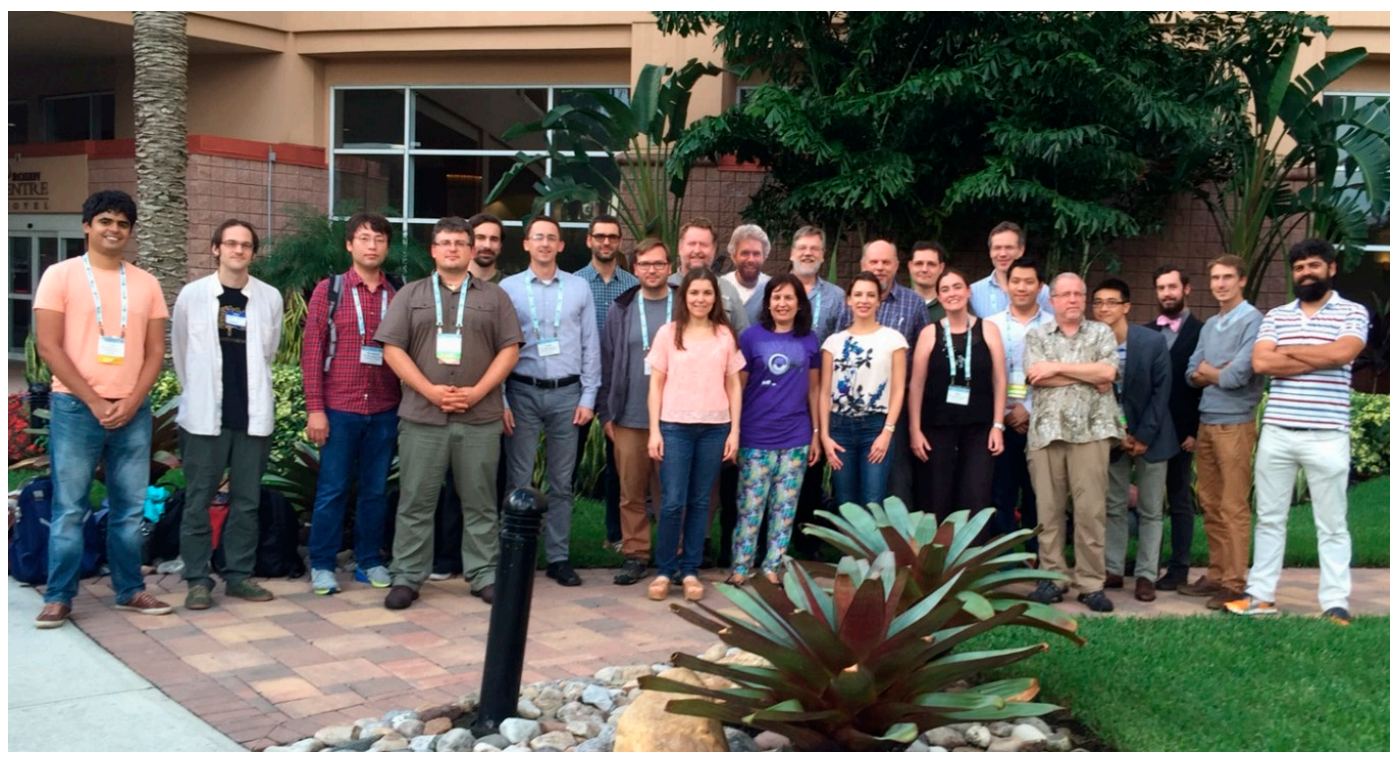

Figure 3. Meeting Attendees (from left to right): B. de Medeiros (Harvard University Museum of Comparative Zoology, Cambridge, MA, USA), S. Davis (American Museum of Natural History, New York, NY, USA), S. Shin (University of Memphis, Memphis, TN, USA), D. Clarke (University of Memphis, Memphis, TN, USA), H. Letsch (University of Vienna, Vienna, Austria), (D. McKenna University of Memphis, Memphis, TN, USA), N. Franz (Arizona State University, Tempe, AZ, USA), M. Van Dam (Bavarian State Collection of Zoology, München, Germany), R. Anderson (Canadian Museum of Nature, Ontario, Canada), A. Marvaldi (CONICET, Universidad Nacional de La Plata, Argentina), S. Brown (Lincoln University, Christchurch, New Zealand), A. Lanteri (CONICET, Universidad Nacional de La Plata, Argentina), C. Lyal (The Natural History Museum, London, UK), L. Chamorro (Systematic Entomology Laboratory - ARS, USDA, Beltsville, MD, USA), R. Oberprieler (CSIRO, Australian National Insect Collection, Canberra, Australia), G. Setliff (Kutztown University of Pennsylvania, Kutztown, PA, USA), G. del Rio (CONICET, Universidad Nacional de La Plata, La Plata, Argen), B. Jordal (University of Bergen, Bergen, Norway), S. II Kim (Harvard University Museum of Comparative Zoology, Cambridge, MA, USA), R. Leschen (New Zealand Arthropod Collection, Auckland, New Zealand), G. Zhang (Arizona State University, Tempe, AZ, USA), R. Whitehouse (Mississippi State University Entomological Museum, Starkville, MS, USA), J. Haran (Centre for Biology and Mgmt. of Populations (CIRAD), UMR CBGP, Montpellier, France), and M. Barrios (Centro Universitario de Zacapa, Universidad de San Carlos de Guatemala). Not shown: S. Anzaldo, C. Beza, P. Biedermann, D. Furth, J. Morillo, R. Mueller and A. Riedel.

Table 1. Affiliations of Attendees *

\begin{tabular}{ccc}
\hline Name & Primary Affiliation & City-Country \\
\hline Robert Anderson & Canadian Museum of Nature & Ottawa, Canada \\
Salvatore Anzaldo & Arizona State University & Tempe, AZ, USA \\
Manuel Barrios & Centro Universitario de Zacapa & Zacapa, Guatemala \\
Cristian Beza & Universidad de San Carlos de Guatemala & Memphis, TN, USA \\
Peter Biedermann & University of Memphis & Jena, Germany \\
Samuel Brown & Max-Planck-Institut for Chemical Ecology & Christchurch, New Zealand \\
Lourdes Chamorro & Lincoln University & Beltsville, MD, USA \\
Dave Clarke & Systematic Entomology Laboratory, ARS, USDA & Memphis, TN, USA \\
Steve Davis & University of Memphis & New York, NY, USA \\
Bruno de Medeiros & American Museum of Natural History & Cambridge, MA, USA \\
Guadalupe del Rio & Harvard University Museum of Comparative Zoology & La Plata, Argentina \\
Nico Franz & CONICET, Universidad Nacional de La Plata & Tempe, AZ, USA \\
\hline
\end{tabular}


Table 1. Cont.

\begin{tabular}{ccc}
\hline Name & Primary Affiliation & City-Country \\
\hline David Furth & Smithsonian Institution & Washington D.C., USA \\
Julien Haran & Centre for Biology \& Mgmt. of Populations (CBGP)/CIRAD & Montpellier, France \\
Bjarte Jordal & University of Bergen & Bergen, Norway \\
Sang II Kim & Harvard University Museum of Comparative Zoology & Cambridge, MA, USA \\
Analia Lanteri & CONICET, Universidad Nacional de La Plata & Llata, Argentina \\
Richard Leschen & Manaaki Whenua, New Zealand Arthropod Collection & Auckland, New Zealand \\
Harald Letsch & University of Vienna & Vienna, Austria \\
Chris Lyal & The Natural History Museum & London, UK \\
Adriana Marvaldi & CONICET, Universidad Nacional de La Plata & La Plata, Argentina \\
Duane McKenna & University of Memphis & Memphis, TN, USA \\
Jose Ricardo Mermudes & Universidade Federal do Rio de Janeiro & Rio de Janeiro, Brazil \\
Jhunior Morillo & The City College of New York & New York, NY, USA \\
Robert Mueller & Western Sydney University & Sydney, Australia \\
Rolf Oberprieler & CSIRO, Australian National Insect Collection & Canberra, Australia \\
Alex Riedel & Staatliches Museum für Naturkunde & Karlsruhe, Germany \\
Gregory Setliff & Kutztown University of Pennsylvania & Kutztown, PA, USA \\
Seunggwan Shin & University of Memphis & Memphis, TN, USA \\
Matthew Van Dam & Bavarian State Collection of Zoology & München, Germany \\
Ryan Whitehouse & Starkville, MS, USA \\
Guanyang Zhang & Tempe, AZ, USA & Arizona State University \\
\hline
\end{tabular}

* Several colleagues who originally intended to take part in the meeting were ultimately unable to attend. These included Miguel Alonso-Zarazaga (several talks had been proposed), Anthony Cognato (had intended to present a talk on Scolytinae), Charlie O'Brien (had intended to present a talk on New World Stenopelmini) and Marek Wanat (had intended to present a talk on Apioninae). ^ Unable to attend, but presented a recorded talk.

\section{Scientific Program}

The 2016 International Weevil Meeting was organized by Duane McKenna and Dave Clarke (University of Memphis) as part of the U.S. National Science Foundation-funded 1K Weevils Project. Meeting conveners included (in addition to D. McKenna and D. Clarke): Robert Anderson (Canadian Museum of Nature, Ottawa, ON, Canada), Chris Lyal (Natural History Museum, London, UK), Adriana Marvaldi (CONICET, Universidad Nacional de La Plata, La Plata, Argentina) and Rolf Oberprieler (CSIRO, Australian National Insect Collection, Canberra, Australia).

\subsection{DAY 1: Weevil Morphology}

2.1.1. Introduction to Cucujiform Systematics and Morphology (Richard Leschen (Speaker); John Lawrence)

Richard Leschen started the morning session with a presentation on the morphology and classification of the series Cucujiformia, with a focus on the superfamily Cucujoidea and the Phytophaga (comprised of the sister superfamilies Chrysomeloidea and Curculionoidea) [1,2]. Among other things, he commented on the characteristic double tegmen in the superfamily Cleroidea (and a few other clear morphological apomorphies of this superfamily), the difficulties of resolving deep relationships in the superfamily Tenebrionoidea and the non-monophyly of Cucujoidea, which is now thought to comprise two groups: Coccinelloidea (the cerylonid group) and the core Cucujoidea (see [3-5]). He went on to discuss general features of the adult and larval morphology of Phytophaga.

2.1.2. Characters, Homology Assessment and 1K Weevils Morphological Phylogenetic Analyses (Dave Clarke (Speaker); Adriana Marvaldi; Duane McKenna)

Dave Clarke provided an overview of the $1 \mathrm{~K}$ Weevils morphology project and discussed theoretical and practical aspects of large-scale morphological dataset construction. He began by outlining the three main goals of the project: (1) Compile a comprehensive dataset sampling 750 genera of Curculionoidea and representing all major lineages of Curculionidae; (2) provide an independent morphological test of weevil relationships by integrating $>700$ adult and immature characters into one framework; and (3) improve the higher classification of Curculionidae (subfamilies/tribes) using subsets of this information for diagnosing higher taxa 
and by comprehensively illustrating and integrating this information into a Lucid (or similar) platform. He introduced his literature-based synthetic compilation of character data from throughout Curculionoidea by describing the relationship between the numbers of new characters introduced to the 'global' character database as new studies of weevils appear over time. From this work, he has developed a consensus character list and database comprising both internal and external characters sampled across Curculionoidea, which tracks the usage of individual characters by various studies and thus widely across weevil phylogeny. He advocated for the use of a structured language for character construction (distinct from anatomical/morphological terminology as discussed by Chris Lyal below), such as that described by [6] and for organizing characters in an anatomically logical way, e.g., by body region. The character database is dominated by adult external characters, with internal and larval characters forming a smaller proportion. Adult characters are comparatively evenly distributed among the body regions/primary anatomical divisions. He noted that many characters are probably not independent and discussed the needed balance between quality and quantity of characters. He outlined aspects of what is meant by 'quality', including the importance of understanding the 'classification of characters' and what this means for character construction and phylogeny inference. For example, he emphasized a distinction between 'neomorphic' characters, e.g., 'new' setae or appearance of novel structures (presence/absence, etc.) and transformational characters (similar to [6]). Neomorphic characters are largely presence/absence or meristic characters, whereas transformational characters can be divided into 10 or more categories. He also discussed the use of explicit criteria for representing homology, e.g., position, fine structure, and connectivity with other structures, as well as the implications of primary homology assessment when this step of a phylogenetic analysis accounts for the various categories and types of morphological characters. In addition to the more obvious positive relationship between increasing taxon and character sampling, an emergent property of the synthesis of morphological character analysis that he is conducting is the notion of character scope (e.g., [7,8]). Characters originally circumscribed for a narrow set of taxa (local area of weevil phylogeny) may require substantial re-evaluation with an expanded taxon sample. Dehiscent mandibular cusps are a potential example of this conceptual problem that was discussed in relation to applying explicit homology criteria to the formulation of character statements (e.g., position, fine structure, connectivity). These cusps are typically associated with adult Entiminae (though cusps, or the scars indicating their dehiscence, are not known from all Entiminae) though Steve Davis noted that some Rhynchitinae and Baridini (Conoderinae) also have such cusps. Their apparent scattered appearance may therefore indicate a kind of developmental homology deeper in the tree, reflecting genes being switched on independently in different groups; that is, reflected as homoplasy in terms of character appearance. It may also reflect an incomplete understanding of 'cusps' at the comparative morphology level. Other examples of this problem include the corbels of Entiminae, which was clarified by Rolf Oberprieler's talk. This methodological problem is therefore of key importance to the $1 \mathrm{~K}$ Weevils morphological study as it incorporates a large and diverse taxon sample involving many characters prone to these and other comparative morphological problems.

\subsubsection{Internal Character Systems (Adults) (Steve Davis)}

Steve Davis spoke about internal character systems of adult weevils. Some of his reported work was pursued using confocal microscopy (with staining) or micro computed tomography (CT) scanning. He noted that there are an abundance of potentially important morphological characters in the mouthparts, including mandibular structure and articulation, and the form and articulation of the pharyngeal plate. He also noted that the pharyngeal structure of Platypodinae shows similarities to Dryophthorinae consistent with recent papers that recover a close relationship between these subfamilies (e.g., [9-12]). The mesonotum was found to exhibit differences useful in separating genera of Curculionoidea and the metanotum provides many useful family-level characters, such as the shapes of the scutellar groove and the metascutellum. The metendosternite is complex across weevils, differing across subfamilies and sometimes within them, but has potentially good characters, 
including from musculature. Other character systems were discussed, including characters of the wings (e.g., general venation; a broad lobe at the base of the costal vein; an acute lobe or spine on the 3Ax sclerite; and in Baridini, variation particularly in the cubitus and radial areas), elytra (which have characteristic wing binding patches, submarginal ridges that may be diagnostic for subfamilies and potentially informative patterns of tracheation), legs (with potentially important characters at the base of the coxa (trochantin/pleurotrochantin), the propleurotrochantin (with different elements differentially elongated in different groups, suggesting independent elongation, e.g., Anthribidae versus Scolytinae)), the abdominal tergum (sometimes strongly sclerotized, sometimes subdivided; with locking mechanisms present), new aedeagal structures (e.g., ventral struts from its posterior side in Dryophthorinae (separate from the larger and well-characterized dorsal struts)) and scale ultrastructure (a loose internal structure of cuticular spheres and webbing in primitive weevils becoming more packed and organized in derived weevils, with photonic crystal lattices in scales of the Cyclominae, Entiminae, Gonipterini and Hyperini (CEGH clade)). Cuticular structure was observed to vary across weevils. Embryological characters are informative, e.g., the ephemeral presence of thoracic leg tissues (which degenerate before egg hatching) in families other than Nemonychidae and Anthribidae (i.e., those families in which the larvae have lost thoracic legs). Additionally, the tracheal system contains potentially useful characters mostly in the thorax and elytra.

\subsubsection{Larval Character Systems (Adriana Marvaldi)}

Adriana Marvaldi discussed the phylogenetic value of larval and pupal character systems. She noted that larval characters, particularly those of the head-capsule and mouthparts, provide useful family- and subfamily-level information [13,14]. Examples include the fronto-epicranial bracon, endocarinal line, shape and setae of the maxilliary mala, palpomere numbers, and the shape of the labral sclerite. Antennal characters are similarly informative, for example, the shape of the sensorium, but this is sometimes difficult to compare across groups. The larvae of Belidae and Attelabidae, for example, have 2-segmented antennae; however, these may not be homologous: Belidae appear to have lost the 1st segment, while Attelabidae may have lost the 2nd segment. The thorax also has useful characters, including the prothoracic shield, which has numerous setae that may be numbered. However, setal numbering may be misleading; the relative position of setae is also significant (in order to ensure comparison of homologous structures). Larval legs are present in Caridae, Nemonychidae, Anthribidae and Brentidae and a pretarsal claw is present only in Nemonyx Redtenbacher and Caridae. The sternellum is only present in larvae of Curculionidae. The thoracic spiracle is located on the prothorax in the larvae of Curculionidae, but is intersegmental or placed on the mesothorax in the larvae of the other weevil families. Regarding abdominal features, typical abdominal segments (usually second to seventh) have three or four transverse dorsal folds in Curculionidae, while other families have only two folds. Within Curculionidae, larval characters can define large groups, such as Entiminae (antennal sensorium cushion-like and elliptical in apical view) and the hypothesized clade comprising Dryophthorinae and Platypodinae (abdominal pleural division). Some characters of weevil larvae are clearly linked to habit [15], for example, the head capsule posteriorly emarginated and labrum with reduced setae in leaf miners, spiracles externally tipped as plant-piercing structures in larvae living in aquatic habitats, the concave labrum shape and abdominal ambulatory lobes or pygopods in aerial plant feeders, and the various adaptations of some larvae to wood boring, such as mandibles with the cutting edge raised and with a grinding surface. Many pupal characters foreshadow adult characters and are therefore not very useful; however, pupa-specific chaetotaxi and the shape of pupal urogomphi can be diagnostic at the genus or species levels, while relatively few pupal features can characterize large groups (e.g., most Entiminae have one to two setae on the mandibular thecae). There are no known distinctions between the pupae of Curculionoidea and those of other Phytophaga. 


\subsubsection{Weevil Morphological Terminology (Chris Lyal)}

Chris Lyal spoke on weevil morphological terminology. Currently, many terms are in use for structures across the weevils, but different terms are often used for the same structures. These differences may be linguistic: whether the term is latinized, in English, or another language; applicable only within the weevils or with a wider homology, such as the antennal nomenclature (scape + pedicel + flagellum c.f. scape + funicle + club); they may reflect a functional rather than morphological terminological basis (penis as a morphological structure c.f. the intromittent organ); or they may relate to nomenclatural precision (tarsomere rather than tarsal segment). Some structures, such as the spermatheca, lack a sufficient terminology, in this case because of the lack of landmarks or, as in the case of the antennal club, because morphological problems are unresolved. Authors may also use their own idiosyncratic terminology. The current situation is confusing and limits engagement; it needs improvement. Agreement on terms is necessary, including clarity on their applicability and whether they represent homology or not, which will particularly assist the reuse of characters in phylogenetic analysis. In that context, it is worth considering whether characters particularly useful for descriptive work and those used in reconstructing phylogeny should be noted as such and authors might consider identifying diagnostic and phylogenetic sections separately in descriptions of new taxa. Reaching for some agreement in terminology requires both open discussion and a means of presenting any conclusions. However, although consensus is important, it is also important to facilitate cross-linking terminological synonyms used by different people; this would avoid such an approach appearing as exclusionary and authoritarian. An output could be an atlas of weevil morphology of all stages, from egg to adult. Certainly, in any development of a resource, images illustrating morphological terminology would be a necessary component. The weevil community could build on the glossary in the Handbook of Zoology [16] and the glossary in the International Weevil Community Website (http:/ / weevil.info/). When possible, we should seek congruence with other terminology used in studies of Coleoptera with an additional set of terms for weevil-specific characters. The platform on http:/ / weevil.info/ is open to all to contribute and might be used both as a discussion forum and the basis of a joint publication by all contributors.

\subsubsection{Evolutionary Development of the Weevil Rostrum (Steve Davis)}

Steve Davis opened the afternoon session with a presentation on the weevil rostrum. He noted that certain Salpingidae (Tenebrionoidea) also have a rostrum (like Curculionoidea), but that the salpingid rostrum differs in having free tendons. In Curculionoidea, the tendons are supported by internal apodemes that extend from the head sulci. He used micro CT scanning to see more detail. He also obtained histological sections across the length of the rostrum from exemplar weevils from different lineages of Curculionoidea and found that apodemes sometimes fuse internally, especially posteriorly. Anteriorly, the pharyngeal plate is supported by apodemes. The weevil phylogeny reconstructed on the basis of rostrum anatomy [9] is similar to phylogenies reconstructed from molecular data (e.g., [10]). He sequenced transcriptomes from the heads of developing weevils and functionally tested (by RNAi) genes for a role in head (and particularly rostrum) morphology and development. His results indicate a wide range of involvement for his previously identified candidate genes in development [17]. Notably, when the gene sex combs reduced (Scr) is knocked out, the posterior tentorial pits appear as paired (they are fused into a single pit in the wild-type), the gula appears (this also reverses the fusion of the ventral head sulci (the subgenal sulci reappear)) and the pleurostomal sulcus also reappears. The pharyngeal plate appears to be a novel structure in weevils, although it may share homologies with the sitophore sclerite in other insects or with the hypopharyngeal sclerite and connecting apodemes in other Coleoptera; the apodemes supporting the plate show a general trend from weak/reduced in basal weevil families to robust and rigid in Curculionidae, possibly serving as an adaptive response to changes in feeding strategies and oviposition behavior. Apodemes (when present) are in two pairs arising from the postmentum (the posterior arms) and the postcoila of the anterior mandibular 
articulations (the anterior arms). The pharyngeal plate is present in Platypodinae but appears to have been lost in Scolytinae (although apodemes remain present).

\subsubsection{Morphological Character Evolution in Scolytinae (Bjarte Jordal)}

Bjarte Jordal introduced his talk on morphological character evolution in Scolytinae by noting that similar adaptations to subcortical life are present in several other groups of Curculionidae. For example, Homoeometamelus Hustache (Conoderinae) produces galleries similar to those produced by Cossoninae (and Scolytinae). Morphological characters have not been well-developed for higher-level studies of Scolytinae, with a strong focus on head, pronotum and elytral declivity. Characters in these body regions are most useful in species identification and were therefore early established as the prime characters for classification. He noted that these body parts are under strong selective pressure in Scolytinae due to specialized courtship behavior in the later arriving, courting sex. Hidden or less extravagant characters have therefore a greater potential for phylogenetic resolution. Examples of such characters include the intersegmental transverse suture of the metanotum, a longitudinal scutoscutellar groove, the elytral locking system anteriorly on the metanepisternum and nodules and pits along the elytral suture. There may also be useful characters in the mouthparts of Scolytinae, as well as along the internal digestive tract, such as the proventriculus [18]. Male genitalia are occasionally used in taxonomy, but exhibit informative characters of greater use at higher taxonomic levels. Care is needed when using generalized characters from the literature and he recommended looking at the actual specimen for studies that rely on these data. Regarding taxon sampling, Scolytus Geoffroy is not representative for the subfamily Scolytinae (e.g., [19]) (also noted by several other speakers). More characters resulting from ongoing work in the Jordal lab will be described and used in the future. Emerging patterns of relationships on the basis of morphological characters are largely congruent with relationships reconstructed from analysis of molecular data (e.g., see [20-22]). However, the deep nodes in the phylogeny of Scolytinae are not supported in the published few-gene molecular data sets: more data are apparently needed to resolve these relationships (see [23]).

2.1.8. Systematics of Neotropical Entiminae: Eustylini and Geonemini (Guanyang Zhang (Speaker); Sara Tanveer; Nico Franz)

Guanyang Zhang presented on the systematics of Neotropical Entiminae: Eustylini and Geonemini. He and his coauthors are also building a larger phylogeny of all groups of Neotropical Entiminae. An analysis of biogeographic trends in the Caribbean Exophthalmus Schoenherr genus complex is now published [24]. In a larger, still unpublished phylogeny that samples more than 200 terminals, Eustylini are recovered in four places, but they think this may be due to limited taxon sampling. They also studied host plant associations in Eustylini, particularly among taxa from Cuba and Central America. They did so by extracting plant DNA from weevil guts. Across various taxonomic ranks, there were variable oligo to polyphagous patterns of host plant usage not consistent with close and well-conserved cocladogenetic or coevolutionary interactions. Adult Eustylini are generally found on fresh shoots of their hosts, and some species can consume and retain in their guts leaves from up to five host plant species at the same time. There is a likely association between weevil and endosymbiont taxa, with unknown connections to host plant usage. Buchner [25] cites a large number of symbionts in weevils. The present study identified 947 bacterial operational taxonomic units, $44.5 \%$ of which were not assigned to genus and many were not assigned at all. Thirty six percent of weevil samples contained bacteria in the genus Nardonella. There was some evidence for coevolution between weevils and their associated bacterial faunas. Results of this broad and exploratory survey are published in Zhang [26]. The talk closed with an introduction to the Symbiota Collections of Arthropods Network (SCAN), which is available to facilitate collaboration at the specimen level (see [27]). 


\subsubsection{Dryophthorinae Larval Morphology (Lourdes Chamorro)}

Lourdes Chamorro presented on Dryophthorinae larval morphology. Of the almost 1200 species and 152 genera classified under Dryophthorinae, approximately 70 species in 29 genera are known by their adult and immature forms. She is currently describing the larvae of 37 genera (representing all currently known taxa), including 7 previously unknown genera. Generally, larvae and adults are found simultaneously within their host plant, which include economically important herbaceous plants, such as banana, sugar cane, bamboo, orchids, and a few in seeds or rotting wood. With a few exceptions prior to pupation, the larvae construct cocoons using plant fibers. She reported on new discoveries of the immature stages of Dryophthorinae, including the possible association of Cryptoderma Ritsema with ferns, as well as clarification and addition of new characters that will aid in the identification and phylogenetic inference of Dryophthorinae.

Among the characters discussed were the terminal abdominal processes, which differ between taxa and may be entire, or with two (Scyphophorus Schoenherr) or six (Sipalinus Marshall and Nephius Pascoe (=Anius Pascoe) digitate processes. In larval Temnoschoita Chevrolat, the anterior and posterior stemmata are visible but difficult to see once the specimen is cleared and the posterior stemmata may only be present in early instars. Another set of very useful characters consist of the number, shape, arrangement and relative size of the malar setae, which, among other states, may be branched/unbranched, may vary in number from 8 to more than 20, may or may not possess mircrosetae or denticles basally and may be arranged in a row or in general clumps. The number of setae, particularly the ventral malar setae, may be variable, but perhaps within limits and can be challenging to count when reduction in size has occurred for one or more of the setae. Malar shape is distinct for Rhynchophorus Herbst and may be an important character to distinguish the larvae of the various subtribes within Rhynchophorini. Setae and the arrangement of these setae and pores on the epipharynx and labrum appear to be among the most important larval features for the subfamily Dryophthorinae; however, terminology and homology of pores, for example epipharyngeal sensory pores, cf. accessory sensory pores and pores of the anterolateral and anteromedian epipharyngeal setae [28], need to be addressed. Mandibles show differences as well as the shape and number of spiracles. vSysLab is used to code characters http://www.vsyslab.osu.edu/. Each image has a unique identifier to link to the specimen, including an annotation of the provenance of each character. This approach allows one to enter characters, view the character state and code each state collaboratively if necessary. It is also possible to export these data to produce a Lucid key (with images) and also create a natural language description for each taxon. The data can also be linked to Morphbank and Zoobank and can be exported as a nexus file. The complete work is published in this volume.

\subsubsection{Logically Reconciling Conflicting Belid Weevil Classifications and Phylogenies (Nico Franz)}

Nico Franz's talk focused mainly on collaboration, data culture and specimen management. In particular, given that weevil phylogenies and classifications are expected to change and conflict with each other for decades to come, he asked how (well) are we keeping up with this change, including in our data repositories? He showed logic-reasoned examples of multi-phylogeny and -classification alignments of different succeeding or simultaneously endorsed arrangements for Belidae (cf., [29,30]). Regarding specimen management, he further introduced the Symbiota Collections of Arthropods (SCAN) as a portal for collaborations involving specimens. As of April 2018, this portal holds $>180,000$ records of $>12,000$ therein recognized species of Curculionoidea. He then talked about the Open Tree of Life Project, including the possibility of using the Pensoft Arpha Writing Tool for collaborative studies of weevil morphology. He proposed a joint paper focused on existing phylogenetic trees for weevils (and other Phytophaga). 


\subsubsection{The $1 \mathrm{~K}$ Weevils Project (Duane McKenna, on Behalf of the $1 \mathrm{~K}$ Weevils Project Consortium)}

Duane McKenna presented an overview of the $1 \mathrm{~K}$ Weevils Project's goals on behalf of the $1 \mathrm{~K}$ Weevils Project Consortium. The weevil family Curculionidae, with approximately 51,000 described species in more than 4600 genera [31], is the largest family of weevils and the second largest family of metazoans [32]. Subfamily concepts and interrelationships in Curculionidae remain controversial, though some natural groupings (e.g., the "higher Curculionidae"; those species with the derived pedal type of male genitalia) have come to light through studies of adult morphology [33-38] and phylogenetic studies employing morphological and/or molecular data $[10,12,14,39-44]$. Nonetheless, outside of the morphologically distinct early-divergent subfamilies Dryophthorinae and Platypodinae, the identity and interrelationships of major lineages corresponding to other subfamilies in Curculionidae remain tentative. This is especially true among the higher Curculionidae. The $1 \mathrm{~K}$ Weevils Project seeks to infer a molecular phylogeny and chronogram (timetree) for the family Curculionidae using phylogenomic data (1000 species, 500 genes [45]), thereby further establishing Curculionoidea as a model system for testing predictions and refining general theories about the evolution of insect-plant interactions. A corresponding morphological study (detailed in a talk by Dave Clarke) will permit independent reconstruction of curculionid phylogeny and assessment of curculionid morphology in light of the results from analysis of these and the molecular data. Both studies are focused on sampling type genera and species when possible. The resulting phylogenetic and temporal hypotheses will provide a framework for investigation of curculionid relationships and evolution and will contribute to resolving the taxonomic problems that pervade curculionid internal higher (subfamilial, tribal) classification. Anticipated direct outcomes from this project include: (1) a deeply gene- and taxon-sampled molecular phylogeny of Curculionidae and relatives (other families of Curculionoidea and select outgroups from superfamily Chrysomeloidea); (2) a corresponding molecular chronogram (timetree); (3) a reconstructed evolutionary history of diversification in Curculionidae, particularly in relation to the rise of angiosperms to floristic dominance and the evolution of weevil-angiosperm interactions; (4) an extensive morphological data matrix and associated phylogeny for Curculionidae and relatives and (5) clarification of group concepts and relationships in Curculionidae based on molecular and morphological data. Additional outcomes include undergraduate, graduate and postdoctoral training and mentoring, teacher training and extensive youth and adult outreach and education.

\subsection{DAY 2: Weevil Fossils, Biogeography, and Host/Habitat Associations}

\subsubsection{Fossil Overview and the Daohugou and Karatau Weevil Faunas (Rolf Oberprieler)}

The day started with a talk by Rolf Oberprieler on the oldest known weevil fossils, those preserved in the deposits of Daohugou in China (ca. 164 Ma) and Karatau in Kazakhstan (163-152 Ma). Whereas the few known Daohugou fossils remain undescribed, those from Karatau have been described as comprising 36 genera and 70 species. Rolf revealed a curious anomaly in the classification of the Karatau fossils following Arnoldi [46] and Gratshev and Zherikhin [47,48] in that the lateral impressions are nearly always classified as Belidae (subfamilies Eobelinae and Oxycorynoidinae) but the dorsoventral impressions as Nemonychidae (in a subfamily Brenthorrhininae). He showed that, if one sorts both types of impression by size and caters for missing features, inaccurate or incorrect depiction of the specimens in the literature and sexual variation as exhibited by extant weevils, the diversity of the Karatau weevils appears considerably smaller. Four size classes are thus identifiable, corresponding to the genera Eobelus Arnoldi, Archaeorrhynchus Martynov, Scelocamptus Arnoldi and Oxycorynoides Arnoldi, each comprising about half a dozen recognizable species. All of them are readily comparable with extant Nemonychidae, although assignment to the extant nemonychid subfamilies Cimberidinae or Rhinorhynchinae is difficult and compromised by uncertainties surrounding critical characters in the fossils (e.g., elytral striae, condition of tarsal segments and claws). He further showed that the Karatau fossils recently described or classified as Anthribidae (including the subfamily 
Protoscelidinae) exhibit no convincing characters of extant members of this family, being either indistinguishable from "brentorrhinines" or not ostensibly representing weevils. There are likewise no fossils known from Karatau that can be assigned to the extant family Caridae. He concluded that the Karatau fauna is in dire need of comprehensive revision and taxonomic reassessment based on the actual specimens, and he acknowledged the invaluable contributions of Willy Kuschel in this evaluation of weevil fossils.

\subsubsection{Yixian Formation Fossils (Steve Davis)}

Steve Davis talked about Yixian formation weevil fossils (Early Cretaceous, Barremian-Aptian, 129.7-122.1 Ma), as well as primitive possible carid taxa being studied from Burmese amber (Early Cretaceous, ca. $99 \mathrm{Ma}$ ) and various basal curculionoids from the Crato Formation (Early Cretaceous, ca. $108 \mathrm{Ma}$ ). Regarding the Yixian weevil fauna, it has been found to thus far largely comprise nemonychids, as well as belids, anthribids and carids that were originally placed in the subtribe Baissorhynchina (Baissorhynchini) [49]. The other subtribe circumscribed within this tribe, Abrocarina, comprises nemonychids. Preservation of this material is quite good in many cases, with structures such as head sutures/sulci, fine setae and details of the meso-and metanota visible, allowing appropriate morphological comparisons with extant taxa and proper taxonomic placement. In regards to a few new Burmese carid taxa, confocal microscopy and micro-CT scanning was undertaken to examine preserved internal features such as the meso- and metanota and metendosternite, features shared with extant Caridae. A review of carid fossils, included in a phylogeny of the family, was presented. Micro-CT scanning also was implemented for several Crato Formation compressions (AMNH material), most representing Nemonychidae or Belidae. Scans of this material revealed finely detailed preservation of external and internal anatomy, including internal apodemes, tendons and musculature. Work on some new Nemonychidae and Belidae from Daohugou (Jiulongshan Formation; ca. $164 \mathrm{Ma})$, China, also was presented.

\subsubsection{Santana Formation Fossils (Jose Ricardo Mermudes (Recorded Presentation))}

Jose Ricardo Mermudes talked about Santana formation fossils by way of a recorded presentation (he did not attend the meeting). He discussed the registry of terrestrial Coleoptera, which was produced as part of the master's degree of his student Márcia F. de Aquino dos Santos. The Santana Formation is from the Araripe Basin and is comprised of sequences of carbonates from the Aptian-Albian, at least 125-112 Ma (Lower Cretaceous), with 300 described species of insects comprising 100 families and 18 orders. Among beetles, the specimens already studied include Carabidae, Buprestidae, Belidae, and Curculionidae. With respect to the species of Curculionoidea described, he noted that Preclarusbelus vanini Santos, Mermudes and Fonseca and Arariperhinus monnei Santos, Mermudes and Fonseca, previously described as Belidae [50] and Curculioninae [51], are now interpreted as Nemonychidae [52] and Brachycerinae [53], respectively.

\subsubsection{The Burmese Amber Weevil Fauna (Rolf Oberprieler)}

Rolf Oberprieler presented an overview of the weevil fauna preserved in Burmese amber. The amber originates from a mine in the Hukawng Valley in Mynamar, is dated as $99 \mathrm{Ma}$ in age and is apparently derived from araucariaceous trees. Numerous insects have been described from Burmese amber, including five weevils (four more specimens have been described since, all mesophyletines). Three of these are classified in a subfamily Mesophyletinae, originally placed in Brentidae but as yet of uncertain affinity, whereas two specimens have been assigned to Curculionidae, one to Molytinae (later to Erirhininae, but unconvincingly so) and the other to Scolytinae. Rolf showed a selection of new weevil fossils in Burmese amber that he and Dave Clarke are studying, comparing their salient observable features with diagnostic characters of extant Nemonychidae, Attelabidae and Caridae. The specimens shown included a clear nemonychid (with a free labrum, falcate mandibles, non-geniculate antennae and punctostriate elytra), a specimen with non-geniculate, subbasal antennae 
and open notosternal sutures (resembling Rhynchitinae but with dentate tarsal claws) and a dozen mesophyletines representing the variety of specimens under study. From these fossils, he characterized Mesophyletinae as having a densely to sparsely setose (never squamose) body, large protruding eyes, no labrum, geniculate antennae with a 7-segmented funicle, exodont mandibles, closed notosternal sutures, punctostriate elytra without a scutellary striole, short trochanters, unarmed femora, often crenulate or serrulate tibiae with two apical spurs and long, deeply lobed tarsi with divaricate, dentate (rarely simple) claws. This combination of characters indicates an affinity with Attelabidae but does not fit in the current concept of this family. Rolf suggested that similar fossils described from other Cretaceous ambers, such as Albicar Peris et al. (Spanish amber), Gobicar Gratshev and Zherikhin (New Jersey amber), Gratshevbelus Soriano (French amber) and Antiquis Peris et al. (French amber), which also show geniculate antennae and a similar body shape, may actually belong to Mesophyletinae and that the group may have been more diverse and widespread in the Cretaceous than is currently recognized. Among almost 100 weevils known from Burmese amber to date, and many thousands of Coleoptera, no additional specimens of Curculionidae have come to light, throwing further doubt on the origin of the two members of Curculionidae described thus far from Burmese amber.

2.2.5. Effects of Insect-Host Interactions on the Diversification of Palm-Associated Weevils (Bruno de Medeiros (Speaker); Brian Farrell)

Bruno de Medeiros presented his PhD thesis work on weevils associated with Syagrus Mart. palms in Brazil. Multiple species of weevils (mostly Derelomini and Bariditae) are associated with flowers of Syagrus [54-61], a genus of palms native to South America and closely related to the coconut $[62,63]$. Based on a review of the literature and extensive fieldwork, he found that the most abundant weevils visiting flowers of Syagrus coronata (Mart.) Becc. and Syagrus botryophora (Mart.) Mart. can be classified into three ecological groups: brood pollinators [64,65], non-pollinators feeding on living tissues, and non-pollinators feeding on decaying palm floral tissues. Among weevils, species in the genus Anchylorhynchus Schoenherr are important pollinators, consistent with congeneric species in other palms [58,61,66-68], while other Derelomini are typically non-pollinators feeding on decaying floral tissues and Bariditae typically feed on living floral tissues. By using double-digest RAD-seq [69] to generate genetic data for both weevils and plants, Bruno is comparing the degree to which beetle population structure is associated with the population structure in their host plants and whether this varies between weevils with different modes of interaction. He also presented his ongoing work to develop PCR-generated target enrichment probes [70] and RAD-seq [71] for reconstructing lower-level phylogenies among the species of weevils associated with palms and also briefly shared highlights from his work mining the literature for information on egg morphospace. Bruno and collaborators developed a database of egg size measurements gleaned from thousands of references and linked this data to phylogenetic information. This could provide a model on how to gather data from the literature to study weevil biology once a comprehensive phylogenetic tree is produced under the $1 \mathrm{~K}$ Weevils project.

\subsubsection{Weevil Habitat Associations and Host Evolution/Coevolution (Robert Anderson)}

Robert Anderson initiated the afternoon session with a talk on weevil habitat associations and host evolution/coevolution. He noted that there is generally sexual dimorphism in rostrum length for most weevils with a strong correlation between female rostrum length and ovipositor length in (at least) species of the genus Curculio Linnaeus [72]. This oviposition deep into host substrates facilitated by the elongate rostrum likely ensures enhanced protection for eggs and larvae from desiccation, parasitism and predation; this also allows weevils to exploit novel food sources not available to other beetles. He also noted the differential taxonomic diversity between angiosperm-associated and gymnosperm-associated groups of weevils. The issue of directionality of host shifts was raised, e.g., is it most typically from gymnosperms to angiosperms or the other 
way around? Clearly, this goes both ways. Blepharida Chevrolat (Chrysomelidae: Chrysomelinae) was given as an example of when host associations are better explained by host plant allelochemicals than taxonomy [73]. Species of various semiaquatic weevils (e.g., Bagous Germar, Notiodes Schoenherr, Listronotus Jekel) are generally associated with unrelated plants likely because these groups of plants live in the same habitat as the weevils [74]. Weevil associations with plants in the family Cyclanthaceae have a recently elucidated complex history with no simple cophyletic basis or host range pattern [75]. Robert introduced his leaf litter project in Central America (LLAMA; Leaf Litter Arthopods of Mesoamerica; https://sites.google.com/site/longinollama/), where he and collaborators sampled at low, middle and high elevations, obtaining distinct faunas at each elevation for each locality sampled. They found that low-elevation sites have more in common with one another than high-elevation sites and there was no overlap between high- and low-elevation sites in their litter weevil faunas. He encountered massive undescribed diversity in these samples and briefly discussed the implications for global weevil biodiversity. Robert gave particular attention to Belidae and Nemonychidae in his talk, including discussion of the new belid genus and species Archicorynus kuscheli Anderson and Marvaldi, which was unexpectedly discovered through his work with LLAMA [76]. The nemonychid genus Atopomacer Kuschel from Central America, which is associated with Podocarpaceae, was also mentioned.

\subsubsection{A Biogeographic Overview of the New Zealand Weevil Fauna (Samuel Brown)}

Samuel Brown reported that the New Zealand weevil fauna includes approximately 1300 described species in 290 genera. In common with many other New Zealand taxa [77,78], the fauna shows evidence of radiations forming from a few lineages that dispersed to New Zealand or persisted through Oligocene inundations [79]. This is demonstrated by the absence of endemic species of several widely distributed clades, such as the Attelabidae, Dryophthorinae, Conoderinae, Lixini, Hyperini, Rhamphini, Bagoini, Nanophyinae and Mesoptiliinae, and with depauperate faunas of Apioninae, Brentinae and Scolytinae. The major clades in New Zealand are the Anthribidae (29 genera), Cryptorhynchini (43 genera), Phrynixini (31 genera), Cossoninae (38 genera), Eugnomini (17 genera), Storeini (18 genera) and Entiminae (40 genera).

The families of Curculionoidea outside of Curculionidae have been well-revised [80,81]. However, substantial work remains to be done on the Curculionidae at both the genus and species levels. The genera of Cryptorhynchini have been comprehensively revised [82] and recent work on the Entiminae is starting to clarify formerly uncertain generic limits [83]. A genus checklist [84] and species checklist [85] have been relatively recently published. Although the classifications used by these checklists do not reflect the current understanding of weevil evolution, Leschen et al. [84] is a useful classification in the New Zealand context in that the major groups within the fauna are clearly delineated.

A hallmark of the New Zealand weevil fauna is high endemism, with 184 endemic genera. Those genera found elsewhere are primarily shared with New Caledonia, Australia, and the South Pacific; with fewer shared with South America and elsewhere. The Cossoninae are the most cosmopolitan of the major groups, with 13 (35\%) non-endemic genera. This proportion of endemism is likely to be slightly exaggerated due to poor understanding of the weevil fauna of the South Pacific. Recent work suggests that greater linkages between New Zealand and the South Pacific will be uncovered as the fauna becomes better known [86,87]. Recent fossil evidence from Miocene sites in Otago indicate a greater diversity of non-curculionid Curculionoidea in the past and a fauna that appears to have been similar to the contemporary New Caledonian fauna [88]. Research on New Zealand weevil taxa has usually been done in isolation. Thus, the monophyly of endemic clades remains untested and their sister taxa elsewhere are unknown. Future research should contextualise the New Zealand weevil fauna to a greater extent by attempting to identify their relationships with taxa from Australia, New Caledonia and the South Pacific. 
A number of New Zealand weevil taxa show unusual life history traits or character combinations with potential to inform hypotheses of weevil classification and evolution on a global scale. These include genera, such as Inosomus Broun, Xenocnema Wollaston, Novitas Broun (Cossoninae), Bantiades Broun, Etheophanus Broun, Phronira Broun (Molytinae), Philacta Broun (Eugnomini), Abantiadinus Schenkling (Storeini), and Myrtonymus Kuschel (Myrtonomini) [89]. Several other endemic weevils have been the focus of ecological research, including sexual selection $[90,91]$ and population dynamics [92]. A sound taxonomic and systematic foundation will unlock the potential of this fascinating fauna for informing more biogeographic, evolutionary and ecological hypotheses.

2.2.8. Evolution of Parthenogenesis in South American Naupactini: Insights into Its Origin and Consequences (Analia Lanteri (Speaker); Marcela Rodriguero; Viviana Confalonieri; Noelia Guzmán)

Analia Lanteri reported that there are repeated independent origins of parthenogenesis in South American Naupactini [93]. Some taxa are infected by different strains of Wolbachia bacteria of supergroup B, which are transmitted through females (infection cannot be transmitted via males). These bacteria may cause male mortality, cytoplasmic incompatibility, or the development of haploid eggs into females [94]. She noted that parasitoids could play an important role in the horizontal transmission of the bacteria [95]. Members of her research group are developing the following projects: (1) a curing experiment using antibiotics to compare infected hosts with artificially cured hosts to test the effects of the bacterial infection on weevil females; (2) studies of ploidy using confocal microscopy in ovocites taken from ovarioles and in embryos; (3) transcriptomic studies on Naupactus cervinus Boheman and Naupactus leucoloma Boheman with the goal of identifying genes related to their colonization capacities (in collaboration with A. Sequeira); (4) hybridization as a possible mechanism for the origin of parthenogenetic reproduction in weevils through the study of intra-individual variation in ribosomal sequences [96].

2.2.9. The Contribution of Mitogenome Sequences to the Reconstruction of the Phylogeny of Weevils (Julien Haran (Speaker); Martijn Timmermans; Alfried P. Vogler)

Julien Haran reported on his collaborative works that used mitochondrial genome (mitogenome) sequences in reconstructing the phylogeny of weevils. The development of high-throughput sequencing of full mitochondrial genomes in beetles [97] has made possible the exploration of weevil phylogenetic relationships based on this relatively large and easy-to-handle sequence dataset (12 protein coding genes, approximately 10,000 base pairs). Phylogenetic analyses were first conducted on 27 taxa, including major basal groups and subfamilies, representing the main lineages of Curculionidae [43]. These data were later included in a dataset of 245 mitogenome sequences of Coleoptera to assess the position of weevils in the order Coleoptera [98]. In parallel, a protocol to assemble new mitogenomes was developed and taxon sampling was increased to 122 species of Curculionoidea [44].

All trees reconstructed from the analysis of mitogenome sequences were consistent with previous molecular phylogenetic reconstructions $[10,14]$. The basal position of families considered as primitive (Anthribidae, Nemonychidae, Attelabidae, Rhynchitidae, Brentidae incl. Nanophyinae, and Apioninae) was supported. The results also supported the existence of an intermediate clade containing the Dryophthorinae, the Brachycerinae, and the Platypodinae at the base of a large clade containing all true weevil lineages (Curculionidae and Scolytinae). Contrary to some previous studies (e.g., [20]), the wood-boring Scolytinae, Cossoninae, and Platypodinae did not form a monophyletic clade $[43,44]$, suggesting strong morphological and behavioral convergence among these groups. In Curculionidae, the largely ectophagous broad-nosed taxa (Entiminae, Cyclominae and Hyperini) formed a monophyletic clade separate from the largely endophagous lineages, highlighting the importance of larval feeding strategy in the early diversification of weevils [43].

Mitogenome sequences robustly recovered the earliest nodes in weevils, thereby "stabilizing" the phylogeny of the superfamily; however, the more recent splits within Curculionidae had lower 
statistical measures of nodal support. Interestingly, translocations changing the order of some mitochondrial genes (t-RNA) were observed among Curculionidae. These translocations are rare in beetles [99] and seem to be more abundant than expected in this family. As they are evidently specific to certain clades, they are potentially useful for identifying the members of those clades (e.g., Entiminae, Hyperini, Sitonini).

The molecular rate of the mitochondrial genome was found to vary substantially between species. Wood-boring lineages, for instance, show a higher mutation rate than the average rate in all other weevil lineages [43]. The causes remain unclear, but this should be taken into account to avoid long-branch attraction artefacts in phylogeny reconstruction.

2.2.10. Timing and Host Plant Associations in the Evolution of the Weevil Tribe Apionini (Apioninae, Brentidae) Indicate an Ancient Co-Diversification Pattern of Beetles and Flowering Plants

(Sven Winter; Ariel Friedman; Jonas Astrin; Brigitte Gottsberger; Harald Letsch (Speaker))

Harald Letsch presented results from some of his collaborative work reconstructing timing and patterns of host plant associations in the weevil tribe Apionini (Apioninae, Brentidae). His work indicates a pattern of ancient co-diversification between Apionini and flowering plants. Most species are monophagous. Host plant use in Apionini is generally conserved, meaning that closely related species feed on closely related plants. Their analysis showed Nanophyinae as the sister group of Brentinae + Eurhynchus Kirby + Apioninae and Antliarhis Billberg as the sister group of Apioninae. Most subtribes were monophyletic and only a few were paraphyletic. Apionini emerged in the Cretaceous $80 \mathrm{Ma}$. The supertribes defined by Alonso-Zarazaga [100] were found not to be monophyletic. Wanat's [101] suggestion of Aplemonini forming the sister group of the rest of Apioninae was supported. Some tribes appear largely restricted to specific host families and host family shifts are rare without any shifts to previous hosts: members of the subtribes Piezotrachelina, Oxystomatina, Trichapiina, and Exapiina are all associated with plants in the family Fabaceae, Ceratapiina with Asteraceae and Malvapiina and Aspidapina with Malvaceae. In contrast, weevils of the subtribe Aplemonina are associated with several different plant families: Tamaricaceae, Polygonaceae, Cistaceae, Hypericaceae, Plumbaginaceae and Crassulaceae. Members of the Kalcapiina feed on Euphorbiaceae, Lamiaceae and Urticaceae. The ancestral host for all Apionini remains ambiguous, with either Fabaceae or "basal Caryophyllales" as potential ancestral host plant groups. The comparison of weevil divergence times with the appearance of their host families indicated a simultaneous occurrence of several families of flowering plants and their occupation by Apionini. The analyses further supported the suggestions by Wanat [101] that Apionini originated in Africa and that only dry-adapted Apionini were able to cross the arid northern African zones facilitated by the distribution of dry-adapted plant hosts. However, the authors' focus on the European fauna meant omission of some African and Asian plant hosts and a potential underrepresentation of host use plasticity. Thus, further work is needed to complete the picture of apionine-host coevolution. He also mentioned ongoing work intended to reconstruct the phylogeny and evolution of Ceutorhynchinae [102].

\subsubsection{The Vexing Corbels of Entiminae (Rolf Oberprieler)}

Rolf Oberprieler gave a short unscheduled talk about the corbels in the subfamily Entiminae. Beginning with pictures of an unmodified tibial apex, which features a circle of fringing setae interrupted on the inside by a pair of socketed spurs (sometimes only one or none) and usually a fixed, perpendicular mucro, he showed that there are three types of corbels that can be derived from this condition: the setose/squamose corbel, the bare corbel and the false corbel. In the first type, the outer tibial edge is bent inwards, first forming a simple bevel without any secondary outer setae, but later such setae develop along the edge of the bend to form a second, outer row of setae that meets the outer row of fringing setae to form a complete circle of setae. In this type, the inner surface of the bevel or corbel is covered with the same setae or scales as occur on the outside of the 
tibia. This type has been referred to as a "closed" or "enclosed" corbel in the past. In the second type, the narrow strip of integument just above the outer row of fringing setae widens to form a narrow, lenticular surface, whose outer edge is demarcated by either a slight rim or a strong carina or a secondary row of setae. The inner surface of this corbel is always bare (devoid of setae or scales). This type has apparently not been recognised in the literature before. In the third type, a flange develops on the inside of the outer row of fringing setae next to the tarsal socket. This flange is almost always bare and never has an inner row of setae. It has been called a "semi-enclosed" corbel in the literature, but it is not a true corbel and has, correctly, been termed a false corbel in the old German literature (e.g., [103]). An "open" corbel, as often named in the literature, refers to the unmodified condition of the tibial apex and in fact signifies the absence of any type of corbel. The distribution of these corbel types among Entiminae requires further investigation, but tibiae without corbels are found mainly in the tribes Brachyderini, Cyphicerini, Ectemnorhinini, Oosomini, Otiorhynchini, Phyllobiini, Sitonini and Tanyrhynchini, setose/squamose corbels in Embrithini, Leptopiini and Naupactini, bare corbels in Leptopiini and Tanymecini and false corbels in Celeuthetini, Ottistirini and Pachyrhynchini. Some tribes appear to have only one type of corbel, whereas in others, such as Leptopiini and Naupactini, several types occur. Outside of Entiminae, setose bevels and corbels are only known to occur in Brachycerinae, whereas bare corbels occur seemingly nowhere else. False corbels, however, are found sporadically throughout Curculionidae. It is imperative both in descriptions and in phylogenetic analyses to accurately identify and code the type of corbels that may be present.

\subsection{DAY 3: Molecular Phylogenetics and Classification of Weevils}

2.3.1. Overview of Genomic Resources for Studying Weevils (Duane McKenna (Speaker); Seunggwan Shin; Asela Wijeratne)

The day started with a talk by Duane McKenna. Beyond discussion of development of the present paper, he discussed the genomic resources available for weevils, stressing that this is a community effort. Resources include transcriptomes and genomes. The 1KITE project is adding many more transcriptomes for beetles, including 10 weevils and is contributing substantially to the development of analytical approaches for dealing with large phylogenomic data sets (e.g., [104-106]). Two scolytine genomes have been published (see [107]), but many more have now been sequenced by the McKenna lab from across the Phytophaga, including another 22 genomes from exemplars of Curculionoidea. He discussed collaborative studies on the glycoside hydrolase family of genes in the Phytophaga, some of which function in the digestion of wood (e.g., [108,109]). He talked briefly about the evolution of genes underlying specialized phytophagy in beetles and how this is related to the macroevolution of specialized plant feeding in weevils and other phytophagous beetles [110]. He also briefly mentioned collaborative studies to reconstruct the evolution of genes involved in color vision in beetles (e.g., [111]) and collaborative studies of olfaction in beetles (e.g., [112]). On a different note, he talked about the biodiversity crisis and specifically the loss of tropical biodiversity, with particular reference to the current status of forests in the Greater Congo Basin (http:/ / tropicalbiology.org/congo-resolution/). He is currently collaborating with researchers in the Democratic Republic of the Congo (DRC) on studies involving the regional beetle fauna, with a focus on forested areas in the eastern DRC. A brief summary was given of the 1KITE beetle project, including the higher-level relationships of beetles, with special reference to the phylogeny of Cucujiformia and Phytophaga. Notably, he shared the observation that Cucujoidea is not monophyletic and forms a paraphyletic grade subtending the Phytophaga. Additionally, he discussed the kinds of molecular data (e.g., genomes, transcriptomes, anchored hybrid enrichment, ultraconserved elements) that his lab is currently using to reconstruct beetle phylogeny and he shared information about several different target enrichment probe sets under development in his lab for studying beetle phylogeny and evolution. These included the probes currently being used across the Phytophaga (including the $1 \mathrm{~K}$ Weevils project [12] and studies of 
Scolytinae [23] as well as ongoing studies of longhorned beetles [45] and Buprestidae) and new probe sets under development specifically for use in the Phytophaga.

\subsubsection{K Weevils Phylogenomic Data and Analyses (Seunggwan Shin (Speaker); Duane McKenna)}

Seunggwan Shin presented a talk regarding phylogenomic data analyses for the $1 \mathrm{~K}$ Weevils Project. This presentation included a general overview of phylogenetics and next-generation sequencing (NGS)-based research for phylogenomics. The goals of the $1 \mathrm{~K}$ Weevils molecular project were described and the data being used to generate a molecular phylogeny for Curculionoidea were discussed. This project was designed to use anchored hybrid enrichment (AHE) to gather phylogenomic data for more than 1000 weevil species (focused on Curculionidae). AHE is a method of sequencing known targeted genes (here, known 1:1 orthologs) using probes, the design of which is taxon-specific. In this presentation, the workflow and general concept of AHE were presented (see $[12,45]$ for more information on the probes and our evolving analytical pipeline). Using our AHE probes we can obtain DNA sequence data from up to approximately 500 genes for each taxon of interest. Long-branched taxa lacking models in the probe set (e.g., Platypodinae) often produce data from somewhat fewer than 500 genes (but rarely fewer than half of the genes). We have been successful in generating AHE data from specimens preserved in EtOH, RNAlater, and dry (pinned) specimens, including some that are more than 30 years old. Additionally, we have sequenced low-coverage (incomplete) draft genomes for nearly 50 beetles, including more than 30 weevils and other Phytophaga, for use in assessing the position of intron-exon boundaries and otherwise refining the selection of target genes/exons and other features of our probe sets.

2.3.3. Unraveling an Adaptive Radiation: Exploring Genomic Data and Phylogenomic Methods in the Eupholini Weevils of New Guinea (Matthew Van Dam (Speaker); Athena Lam; Alex Riedel; Michael Balke)

Matthew Van Dam spoke about the use of phylogenomic data (ultraconserved elements) for inferring the phylogeny of the Eupholini of New Guinea. Ultraconserved genomic elements [113] have been used in a wide variety of organisms to help resolve both young and old evolutionary radiations. His study aimed to test their use in a tribe of weevils, the Eupholini, found throughout Australasia [114]. Eupholini represent an ecologically diverse clade of weevils found from sea level to the alpine grasslands of New Guinea. The uplift of New Guinea's Central Highlands may have created ecological opportunities for the diversification of Eupholini, resulting in many novel ecomorphologies, such as in the subgenus Symbiopholus Gressitt, which has pitted elytra and specialized setae that promote the growth of epizoic symbiosis for camouflage [115]. He and his colleagues examined whether the diversification of the New Guinea Eupholini coincided with the uplift of the Central Highlands. In addition to the collection of fresh specimens, they also utilized museum specimens as a genomic resource. They used both concatenated (RAxML [116]) and species-tree (ASTRAL-III and SVDquartets $[117,118]$ ) analyses to examine the relationships and taxonomy of this group. Their findings demonstrated that the current taxonomy renders polyphyletic many of the clades recovered in the analysis, largely grouping species on the basis of similar coloration. In addition, they demonstrated that the majority of loci require multiple partitioning strategies for nucleotide rate substitution. They were successful in gathering hundreds of loci from the nine museum specimens used. Lastly, an elevated speciation rate did coincide with the uplift of the Central Highlands. Highlights from this research can be found in [119].

\subsubsection{Bark and Ambrosia Beetle Phylogeny and Diversification (Bjarte Jordal)}

Bjarte Jordal presented a talk on bark and ambrosia beetle phylogeny and diversification. A range of interesting behaviors in the subfamily makes the group very useful for studies on evolution. Different reproductive systems have evolved multiple times, such as monogyny, bigyny, harem polygyny, parthenogenesis and permanent inbreeding, as has fungus farming and intricate associations with host 
plants. Previous attempts to establish a robust phylogeny of the group have failed, particularly due to the lack of resolution at basal nodes. A recent study focused on PCR screening of 100 genes, resulting in 16 promising markers and 13 that were ultimately used for phylogenetics [22]. Some improvement was obtained in the present study, with increased, albeit still limited, resolution of basal nodes. Comparative analyses of diversification indicated a very rapid adaptive radiation by the permanently inbreeding and fungus-cultivating lineage Xyleborini beginning around $20 \mathrm{Ma}$ : the highest speciation rate for any lineage of Scolytinae. More detailed analyses using the software SLOUCH revealed significant effects of inbreeding and deep host shifts for the diversification of the subfamily [120]. High diversification rates were further emphasized by the likely high levels of cryptic species in some inbreeding lineages, e.g., Hypothenemus eruditus (Westwood) and allied species groups [121]. Over larger evolutionary time spans, it is also clear that radical host shifts have facilitated high diversification rates given the radically new host opportunities in these lineages.

\subsubsection{Phylogeny of Dryophthorinae (Lourdes Chamorro)}

Lourdes Chamorro presented a preliminary Bayesian phylogeny of Dryophthorinae based on two molecular markers, $18 \mathrm{~S}$ and $28 \mathrm{~S}$ rRNA, aligned using primary and secondary structure. The analysis included a broad sampling of 67 taxa, 2 platypodine outgroup taxa and 65 ingroup taxa representing all 5 tribes of Dryophthorinae and all but one subtribe, Ommatolampina, and a putative African lineage that includes Ichthyopisthen Aurivillius, Korotayeavius Alonso-Zarazaga and Lyal, etc. Results support a monophyletic Dryophthorinae; however, a long branch subtended the clade suggesting a need for broader outgroup sampling. The small, generally detritovorous dryophthorine tribes Dryophthorini and Stromboscerini were each monophyletic and sister taxa. This clade was in turn sister to a monophyletic Orthognathini; however, this was not strongly supported (posterior probability (PP) was below 95\%). The Rhynchophorini was also monophyletic, albeit also with less than 95\% PP support, with the possible inclusion of Cryptoderma Ritsema, which is currently classified in its own tribe as the Cryptodermatini within this clade. She provided an overview of known host plant preferences and possible evolutionary shifts of these preferences among major groups within dryophthorines. She is currently working to add additional molecular markers as well as morphological data of the adults and immatures. She concluded with an overview of ongoing efforts to generate two-dimensional (2D), and possibly three-dimensional (3D), images of all North American weevil types housed at the United States National Museum (USNM). These images and corresponding occurrence data are being made available through the Symbiota Collections of Arthropods Network (SCAN) as part of the Weevils of North America (WoNA) project http:/ / scan-bugs.org/portal/ checklists / checklist.php?cl=1\&proj=\&dynclid=0.

\subsubsection{Structurally Aligned rRNA Sequences and Weevil Phylogeny (Adriana Marvaldi)}

Adriana Marvaldi presented a talk on structural alignment of sequences of the ribosomal markers 18S (complete), 28S (D2 and D3), and 16S (IV and V) performed for phylogenetic analysis of weevils. She constructed an annotated alignment for about 270 weevils plus 30 outgroup taxa using as reference the structural model of rRNA as currently predicted for Arthropoda, including beetles [122,123]. A well-resolved tree was produced, but resolution was least in Curculionidae, especially in the CCCMS (Curculioninae, Conoderinae, Cossoninae, Molytinae, Scolytinae) clade. Addition of the protein-coding mitochondrial cytochrome oxidase I (COI) gene improved resolution. The main higher-level relationships found involve: the paraphyly of Nemonychidae, whereby the bulk of included taxa formed a basal weevil clade but part was resolved as closer to Anthribidae: (Nemonyx (Urodontinae (Anthribinae))); the monophyly of Belidae and Attelabidae as well as of their two respective subfamilies; and the placement of Caridae as sister group of the clade Brentidae + Curculionidae. The main relationships in Curculionidae worth mentioning were: non-monophyly (forming a basal grade) of Brachycerinae (incl. Erirhininae); Dryophthorinae and Platypodinae were sister taxa; recovery of a clade of "higher" curculionids (with a pedal type of male aedeagus) divided 
into two sister clades, the CEGH clade (Cyclominae, Entiminae, and allies) and the CCCMS clade. She proposed that it could be helpful to develop a matrix or resource of annotated secondary structural alignments to be available for updates and for use as a template for further phylogenetic analyses of weevils or beetles. Through discussion, Bjarte said that he pursued something similar for 28S (D2-D3) in scolytines but did not find it of great use in providing much more resolution. Duane commented that he and collaborators did this for 28S, 18S, and 16S in Curculionoidea but ultimately decided not to publish the results because they did not noticeably improve resolution in the resulting phylogeny. Adriana insisted that it is still worth the effort to align by structure because it uses a biological criterion to objectively identify homologous positions within length-heterogeneous alignments and to recognize regions of ambiguous alignment.

2.3.7. Some Outstanding Phylogenetic Problems in Broad-Nosed Weevils: The Entiminae, Cyclominae and Allies (CEGH clade) (Adriana Marvaldi; Rolf Oberprieler)

Adriana Marvaldi and Rolf Oberprieler gave a combined talk on the current composition and classification of the CEGH clade, the so-called "broad-nosed weevils", comprising the current subfamilies Cyclominae and Entiminae and the tribes Hyperini, Gonipterini, Viticiini and Phrynixini. Adriana spoke about the CEGH clade and the subfamily Entiminae (e.g., [124]), and this talk was followed by Rolf's exposition on the Cyclominae, Gonipterini and Hyperini (e.g., [125]). The CEGH clade is characterized by usually possessing a short, broad rostrum that is not used in oviposition and by larvae feeding ectophytically on roots in the soil or on aerial plant parts, although the larvae of a number of taxa, especially Cyclominae, bore in stems, trunks or roots (are endophytic). Common characters (putative synapomorphies) of the group include the largely sclerotized, bilobed basal part of sternite IX (c.f., y-shaped with only the arms sclerotized) in the male genitalia, the unarmed or mucronate (not uncinate) meso- and metatibiae and the three-dimensional photonic crystals embedded in a nano-scale chitin lattice in their iridescent scales (in Entiminae, Cyclominae, Hyperini and Viticiini). Although the latter character is proposed as a putative synapomorphy of the CEGH group (to be further investigated), such scales also occur in some Australian genera currently placed in Storeini (though it is likely that these are misclassified and actually belong in the CEGH clade), some Tychiini (both tribes currently in the CCCMS clade of Curculionidae) and in Cerambycidae. The subfamily Entiminae (e.g., [124]), comprising ca. 12,000 described species placed in 1370 genera, includes mainly taxa that were grouped in the section Adelognatha of old classifications. Most have soil-dwelling larvae (few exceptions) and many are polyphagous, some parthenogenetic. The subfamily is indicated to be a monophyletic group based on a number of synapomorphic characters in the adult (e.g., the mandibles typically have deciduous mandibular processes or their scar when broken off) as well as in the larva (two larval characters have been proposed as supporting the monophyly of entimines), but it has not yet been shown to be monophyletic in molecular analyses [12,124]. Its classification into tribes (currently 55) is highly artificial and unsatisfactory, with most indicated to be para- or polyphyletic. Adriana also emphasized that members of tribe Thecesternini lack those above-mentioned entimine features as well as the CEGH apomorphies in spite of the fact that they have a short rostrum and subterranean larvae. She suggested that they belong instead in the CCCMS clade based on the larvae having the des 3 setae on the epicranium and the adults having strikingly uneven elytral sutural flanges. Rolf then provided a synthesis of the Cyclominae. This largely southern-hemisphere subfamily, including ca. 1550 species in 148 genera (currently in 8 tribes), also generally has larvae that live in soil, feeding on or in roots and underground stems. The group is probably not monophyletic in its present composition, lacking any clear synapomorphies. As those of Entiminae, cyclomine larvae have the des3 setae on the frontal line or on the frons (but this seems to be symplesiomorphic). Of the eight current tribes, Cyclomini, Amycterini and Hipporhinini are indicated to be monophyletic but the others not $[125,126]$. The tribe Hyperini, a cosmopolitan group comprising ca. 500 species in 44 genera, is characterized by ectophytic and ectophagous larvae (though some mine in leaves, e.g., Gerynassa Pascoe) and a meshed cocoon made from fibers secreted by the Malphigian tubules (a putative synapomorphy), but its concept and 
definition are unclear (no morphological characters indicating monophyly have been found) and the northern- and southern-hemisphere faunas may not be closely related. The small Australo-Pacific tribe Gonipterini (ca. 130 species in 9 genera) is monophyletic based on its peculiar internal proventricular projections. Adults and larvae generally feed on leaves and known larvae are ectophytic, but the larvae of the longer-snouted genera are unknown and probably endophytic. Other tribes and genera indicated to belong in the CEGH clade are the also small tribes Viticiini and Phrynixini (except the Syagrius Pascoe group, likely belonging in Molytinae). The Australo-Pacific tribe Viticiini (18 species in 8 genera, forming two groups) is probably monophyletic but no autapomorphies have been identified for it as yet. Its known larvae are all leaf miners. The Australo-Pacific tribe Phrynixini is not monophyletic in its current concept in that the Syagrius group belongs in or near Molytinae. Phrynixine larvae probably develop in leaf litter (as known for Geochus Broun). Although the CEGH clade is well-supported in all recent molecular analyses, relationships within the group are unresolved and will remain elusive until much larger taxon sets can be analyzed. It is likely that more subfamilies need to be recognized in it but fewer tribes in Entiminae. Adriana and Rolf discussed a number of topics mainly related to the fact that monophyly of these diverse groups has not been properly tested yet. For those groups that have been studied (and their monophyly supported/suggested), their position in the subfamily or family Curculionidae nevertheless remains unclear. At lower levels, several tribal concepts are controversial, e.g., that of Tropiphorini in Entiminae.

2.3.8. Big Blocks and Little Blocks: Phylogeny of the CCCMS Clade (Curculioninae, Conoderinae, Cossoninae, Molytinae, Scolytinae) (Chris Lyal)

Chris Lyal provided an overview of the members of the CCCMS clade and some of the problems that need addressing. This clade, comprising 12 subfamilies recognized in [127] (Baridinae, Ceutorhynchinae, Conoderinae, Cossoninae, Curculioninae, Lixinae, Mesoptiliinae, Molytinae, Cryptorhynchinae, Orobitidinae, Scolytinae, and probably Xiphaspidinae) has been recovered in several molecular analyses as one of the two major clades of the higher weevils [10,12,43,44,128]. Its sister group, the CEGH clade, is discussed by Marvaldi and Oberprieler in this paper (see above). There is some support for the CCCMS clade from morphological characters: elytro-tergal stridulation [129] may be apomorphic for the clade and sclerolepidia [130] may be apomorphic for a clade excluding Scolytus Geoffroy and its close relatives, although no analysis has yet been carried out to test these propositions and more work is needed. The ranks given to the family-group taxa vary $[127,131,132]$, but whatever the rank there are some 244 family-group taxa currently included. Twenty-nine of the 244 contain only a single genus and may be assumed to be monophyletic, but fewer than $50 \%$ of the others have had any hypothesis of monophyly presented, including only five of the subfamilies listed above. The others may be paraphyletic or even polyphyletic. The large subfamilies Molytinae and Curculioninae lack any known autapomorphies; Cryptorhynchinae may lie inside Molytinae; Cossoninae have many character states uniting them but none appear to be unequivocally autapomorphic; and Baridinae and Conoderinae are not demonstrably monophyletic. Lixinae may be monophyletic but their sister-group is unknown. Scolytinae increasingly appear to be paraphyletic with respect to the rest of the CCCMS clade.

The current situation is not conducive to successful studies of higher-level relationships; genera cannot easily be taken as representing subtribes or tribes if these are not demonstrably monophyletic and thus applying family-group names to tree branches lacks clear meaning. This may be addressed by developing and testing hypotheses of monophyly for extant higher taxa. The option of sampling thousands of genera is probably unrealistic and so reducing this number to a few hundred units, the monophyly of each of which is testable, seems a sensible move. Undoubtedly, other clades will become apparent whether there is a formal name available for them or not. From this, it is more feasible to develop trees at the higher level. It is also important to understand the sampling intensity necessary to deliver a robust tree; e.g. the tree in [79] is far more coherent for Old-World Cryptorhynchini than 
other cryptorhynchines and Molytinae with a lower sampling density. Establishing phylogenetically reliable bricks may help us build the larger construction that is the phylogeny of the CCCMS clade.

2.3.9. Regional Databases in Curculionidae: An Example for the Naupactini (Curculionidae: Entiminae) from Argentina and Uruguay (M. Guadalupe del Río)

Guadalupe del Río talked about cybertaxonomy (e-taxonomy = web-based taxonomy) and how systematics has evolved, integrating standardized electronic tools, cyber-infrastructure, computer science and computer engineering. Through user-friendly interfaces, these tools make it easier for taxonomists and the general public to identify species and access the world's total knowledge of biodiversity [133]. She gave a screenshot of the main biodiversity portals, e.g., taxonomic data (Antweb, Avibase, FishBase, species file OSF); biodiversity data (GenBank, iBol, BOLD); morphological data (Morphbank); phylogenetic data (Tree of Life); biodiversity initiatives (Species 2000, GBIF, CoL, EOL); bibliographic information (Biodiversity Heritage Library); and tools for registration and recovery of taxonomic collections (life science identifiers [LSIDs], Darwin Core, digital object identifiers [DOIs]). In the case of weevils, there is an International Weevil Community Website [134] that facilitates cooperation and information sharing worldwide and that also includes a very useful glossary of weevil structures [135]. There are several other websites, for example Wtaxa: Electronic Catalogue of weevil names [136], New Zealand weevil Images [137], Potential invasive weevils of the world [138], Coleoptera Neotropical [139], Symbiota Collections of Arthropods Network (SCAN) [140] and Beetles and Coleopterists [141] among others.

Analía Lanteri and M. Guadalupe del Río generated a regional database of "Naupactini (Curculionidae: Entiminae) from Argentina and Uruguay" that includes more than 120 species, some of which are also distributed in other South American countries and have been introduced in other continents. For each species, the authors give the synonyms, a short diagnosis in English and Spanish, complete data of distribution, host plants and biological observations. This information is complemented with pictures of adult females and males and maps of their distribution in Argentina and Uruguay. The database will be available through the "Portal of Biodiversity of Insects from Argentina" hosted at CEPAVE (Centro de Estudios de Parásitos y Vectores, CONICET-UNLP) and will facilitate the rapid identification of naupactines harmful to agriculture.

\subsubsection{Comments on Weevil Classification (Contributed by Guillermo Kuschel; Read by Richard Leschen)}

Guillermo (Willy) Kuschel dictated various topics to Richard Leschen who presented these after a brief introduction to Willy's career [36] that highlighted weevil specialists who had studied in or visited New Zealand. Ventral structures of beetles: The current sternal structures of beetles are based on the invagination of what are thought to be primitively external structures and referred to as meso-, meta-, or abdominal ventrites. This is not acceptable to Willy, who maintains that the structural homologies as presented by Snodgrass and others are more accurate. Terminology: Willy was a linguistic scholar and adamant about proper syntax and names and he had disdain for inadequate use of Greek and Latin with respect to taxonomy and morphological terminology. Morphology: The embryonic origin of the dermal layers of the fore- and hind-gut informs the origin and naming of the male genitalia, and Willy believes that David Sharp's work in this regard was exemplary. Classification: The most vexing problem in weevil classification to Willy is the placement of Cossoninae and that host plants should be used as phylogenetic characters to help resolve systematic problems in weevil phylogeny.

\subsubsection{Curculionidae Classification: Viewpoints and Vision (Chris Lyal)}

Chris Lyal discussed his work on the classification of Curculionidae. An overarching vision is of a time when we know everything about weevil phylogeny, when fitting new taxa into the model is simple, when phylogeny illuminates hypotheses of biology and evolution and when we can address novel questions based on a clear phylogenetic framework supported by a digital databank of all known 
information about weevils and their associations. Until then ... we are currently in a key position. We have a working community that is building on a long-term engagement around the goal of a functioning classification based on phylogeny and with a recent record of successful interactions in creating the Handbook [142]. We are using multiple methodologies, but these are increasingly interlocking. Our observational precision is improving: the reports by Oberprieler on weevil fossils and of Davis on the weevil rostrum above are outstanding examples of this. We are already sharing information well and have the opportunity to design and build an information system to support our studies. Data management and analysis systems are improving greatly; genomic data and new analytical tools are opening doors to novel insights. Much of what has been discussed in the workshop has been academic and the academic progress is considerable. However, we are living through a biodiversity crisis and we need to develop the use of academic research to combat this. As we progress we should consider the ways in which our work can be at the forefront of effective biodiversity information provision. How do we make host information available? How do we inform Invasive Alien Species risk analysis? How do we develop and disseminate identification tools suitable for use by non-specialists around the world? We need to consider how our outputs can be made multi-purpose, so that what we discover is valuable for non-specialists and made available to them to solve real-world problems. My vision, therefore, is that we carry on with intellectually challenging and rewarding research and use it to safeguard biodiversity and human livelihood.

\section{Posters}

3.1. Introductions and the Potential for Interspecies Gene Flow in Endemic Galápagos Weevils (Entiminae: Naupactini) (Andrea Sequeira (lead author); Flavia Mendonca de Sousa; Sarah Pangburn; Sara Eslami; Mary Kate Dornon; Anna Hakes)

We aimed to study the potential for interspecies gene flow between introduced and endemic Galápagos weevils (Entiminae: Naupactini). Introduced species can threaten endemic species through competitive exclusion, niche displacement, introgression, predation and hybridization [143]. As a result of hybridization, endemic species can lose important adaptations. Small-island populations of endemic species may be especially threatened due to hybridization with introduced close relatives [144]. The weevil genus Galapaganus Lanteri contains 15 species [145]. Thirteen of these species are flightless and 10 are endemic to the Galápagos Archipelago. Phylogenetic reconstructions propose that a Galapaganus ancestor colonized the archipelago between 8.6 and 11.5 million years ago from continental Ecuador [146]. The proposed scenario is that original colonizers reached now submerged seamounts, later colonizing the younger islands that exist today. One member of the Galapaganus genus, G. h. howdenae Lanteri, has a very different colonization history into the islands: it was accidentally introduced into Santa Cruz from mainland Ecuador with the aid of humans. Genetic estimates indicate that this occurred during the colonization period (1832-1959) $[147,148]$ prior to the spurt in human population growth on the island. The six Galapaganus species we focused on included five endemics and one introduced species in two islands: G. h. howdenae, G. conwayensis Lanteri, and G. ashlocki Lanteri (in Santa Cruz Island) and G. galapagoensis Lanteri, G. collaris Lanteri, and G. vandykei Lanteri (in San Cristóbal). Range expansion of G. h. howdenae into the highlands prompts us to ask if the introduced population could be hybridizing with the highland endemic G. ashlocki, which is also a single-island endemic. We predicted that if hybridization is occurring and is recent, larger estimates of genetic exchange should be found between the introduced G. $h$. howdenae and the Santa Cruz endemics G. conwayensis and G. ashlocki. Moreover, the effects of hybridization should be greater when analyzing patterns with mitochondrial DNA than with nuclear DNA due to the maternal inheritance of mtDNA.

We estimated six parameters for six pairwise comparisons using IMa2 [149,150] using mitochondrial and nuclear DNA sequence datasets. The estimated parameters included migration rates in both directions (m); a time estimate for when the ancestral population diverged into the two populations $(\mathrm{t})$; population sizes dependent upon the mutation rate $(4 \mathrm{mu})$; and the overall effect of migration (2Nm). IMFig [151] was used to obtain significance values for $2 \mathrm{Nm}$. The largest 
migration rate estimate $(\mathrm{m})$ using mitochondrial DNA was found to be between Santa Cruz species from G. howdenae to G. ashlocki. The mitochondrial $2 \mathrm{Nm}$ values, which give an overall estimate of the effect of migration, show the highest, significant results from the endemic G. ashlocki population to the introduced G. h. howdenae population. These results indicate recent gene exchange between the endemic and introduced populations, but because population size estimates for G. ashlocki were larger than those of G. h. howdenae, the effective gene exchange appears to be in the opposite direction as expected. In any case, our results suggest mitochondrial gene exchange between endemic and introduced Galapaganus.

The "El Niño" events and subsequent "La Niña" droughts, which affect the islands approximately every ten years, most often cause natural range expansions and provide opportunities for range overlap between previously allopatric populations and species. The expansion of the range of the introduced G. h. howdenae and the endemic G. conwayensis into the highlands is an example of one of those natural mixtures. Our results provide genetic evidence of the effects of the recent introduced population expansion into the highlands and suggest that an introduced population could have an impact despite low population size or low genetic variation and possibly independently from their competitive abilities. This gene exchange between endemic and introduced species has possible genetic impacts: possible loss or gain of variation and loss or gain of adaptation in the endemic species as well as blurred species boundaries [152], which could lead to the complete loss of the genetic identity of the endemic species. Gene exchange between introduced and wild populations has been documented in species of Viola L. [143], smooth cordgrass [153], and tiger salamanders [154]. In the case of the salamander, the speed of spread of introduced alleles into an endangered species underscores the importance of the genetic impact of an introduction even in the absence of ecological dominance. Within the Galapágos, G. h. howdenae has been introduced only in Santa Cruz to date. Even though the existing barriers to its dispersal to other islands are effective, they are not insurmountable. As a result, G. h. howdenae adults could disperse, via flight or transportation on plants that are exported from Santa Cruz, to other islands, such as Isabela, and potentially encounter and impact populations of other endemic Galapaganus.

\subsection{The Molecular Weevil Identification (MWI) Project (André Schütte; Peter Stüben; Jonas Astrin (Correspondence))}

Since 2011, the Molecular Weevil Identification (MWI) project has strived to build a starting infrastructure for DNA-based research on European and Macaronesian species of Curculionoidea and to foster research on this group of beetles. MWI aggregates CO1 barcodes and centrally archives tissue vouchers, DNA vouchers and a morphological collection. The project involves the Zoological Research Museum Alexander Koenig (ZFMK) in Bonn, Germany, in conjunction with the pan-European entomologists' association Curculio-Institute (CURCI), which is based in Mönchengladbach, Germany.

The early steps in the MWI workflow center on the robust morphological identification of the reference specimens performed by taxonomic and faunistic experts within CURCI. Using these same (subsequently pinned) specimens, we then generate DNA barcodes to validate the morphological identifications and to serve, in combination with these, as the scaffold for ensuing integrative taxonomic research. Several 'cryptic' species and synonyms have already been identified within MWI [155-159], with a strong focus on the subfamily Cryptorhynchinae. In its last project phase, MWI now investigates, among other aspects, the feasibility of using 'barcode gaps' in a quick approximation to pre-assign unknown specimens to species or to get a first heuristic hypothesis on species limits that will be subsequently tested by additional evidence (morphology, ecology). While a general barcode gap for such a diverse group of organisms would not hold, adapted gap values can still be conveniently applied for the various taxonomic and ecological groups.

Currently, the MWI reference database contains roughly 1400 species, with usually several specimens per species, from 330 genera $[160,161]$. Using synergies with the ZFMK-coordinated project German Barcode of Life (www.bolgermany.de), a regional sampling focus of MWI lies on the weevil 
species occurring in Germany. In summary, MWI compiles a validated reference database with DNA barcodes of western Palearctic weevils (to be released soon) and offers cross-linked morphological and molecular collections that we encourage entomologists to use.

\subsection{Taxonomy and Evolution of New Zealand Broad-Nosed Weevils (Coleoptera: Curculionidae: Entiminae) (Samuel D. J. Brown, Karen F. Armstrong, Barbara I. P. Barratt, Rob Cruickshank, Craig Phillips).}

New Zealand has a diverse broad-nosed weevil (Coleoptera: Curculionidae: Entiminae) fauna, which is particularly speciose in alpine regions of the southern South Island [83,162]. A number of species show remarkable sexual dimorphism, where females possess exaggerated structures on the elytra and abdominal ventrites [83]. These structures can be classified into five forms: (1) tubercles at the top of the elytral declivity; (2) prolongation of the apex of the elytra; (3) swelling of the disc of ventrite V; (4) emargination of the apex of ventrite V; and (5) the posterior margin of ventrite IV produced into a lamina. The evolution of these structures is of interest from systematic and functional morphological viewpoints. A phylogeny was inferred from four gene regions (28S, COI, ArgK, and $\mathrm{CAD}$ ), sequenced from 316 individuals representing 106 species and a species tree inferred using ${ }^{*}$ BEAST. Sexually dimorphic traits were scored and mapped onto the tree. Competing hypotheses of trait evolution were evaluated using BiSSE and Markov models. Sexually dimorphic species had a greater speciation rate, indicating that some form of sexual selection is in operation. It is hypothesized that this takes the form of sexual conflict through energetic costs incurred by females carrying males during prolonged copulation. The evolution of the number of dimorphic traits was best modeled with a progression model, where transitions between $n->n+1$ traits had greater rates. Laminae on ventrite IV are labile and plesiomorphic within NZ Entiminae; however, these structures may prove to be apomorphic at higher levels of entimine weevil systematics.

\section{Conclusions}

The 2016 International Weevil Meeting, convened by researchers from the $1 \mathrm{~K}$ Weevils Project (funded by the U.S. National Science Foundation), was a success in catalyzing research and collaboration (particularly involving the $1 \mathrm{~K}$ Weevils Project) and serving as a forum for identifying priorities and goals for those who study weevils. The meeting collectively hosted 46 invited and contributed lectures, pre-arranged discussion sessions and introductory remarks presented by 23 speakers along with eight contributed research posters. This report presents a summary of the meeting, with a focus on invited and contributed lectures and select posters, including new research findings and ideas contributed via these contributions. We hope that this report will be followed at regular intervals with others reporting on future such meetings.

Author Contributions: Conceptualization, D.D.M., D.J.C., A.M., R.G.O.; Writing-Original Draft Preparation, D.D.M., D.J.C., R.A., J.J.A., S.B., L.C., S.R.D., B.D., B.d.M., J.H., G.K., N.F., B.J., A.L., R.A.B.L., H.L., C.L., A.M., J.M., R.O., A.S., A.S., S.S., M.V., G.Z.; Writing-Review \& Editing, D.M., D.C., R.A., J.J.A., S.B., L.C., S.D., B.D., M.G.d.R., J.H., N.F., B.J., A.L., R.A.B.L., H.L., C.L., A.M., J.R.M., R.G.O., A.S. (André Schütte), A.S. (Andrea Sequeira), S.S., M.H.V.D., G.Z.; Project Administration, D.D.M.; Funding Acquisition, D.D.M.

Funding: This research was funded in part by the United States National Science Foundation grant number DEB1355169 to DDM, the University of Memphis and the Entomological Society of America.

Acknowledgments: Thanks are extended to Rosina Romano and Becky Anthony (Entomological Society of America) for assistance with logistics at the meeting venue. This meeting would not have been possible without the substantial time and energy contributed by the program conveners. We would also like to thank the coauthors of presentations: John Lawrence, CSIRO, Australian National Insect Collection, Australia (Leschen); Sara Tanveer, Arizona State University, Tempe, AZ, USA (Zhang); Brian Farrell, Museum of Comparative Zoology, Harvard University, Cambridge, MA, USA (de Medeiros); Marcela Rodriguero, Viviana Confalonieri, and Noelia Guzmán, CONICET, Universidad de Buenos Aires, Argentina (Lanteri); Martijn Timmermans (Department of Life Sciences, Natural History Museum, London, United Kingdom; and Department of Natural Sciences, Middlesex University, Hendon Campus, London, United Kingdom), Alfried Vogler (Department of Life Sciences, Natural History Museum, London, United Kingdom; and Department of Life Sciences, Imperial College London-Silwood Park Campus, Ascot, United Kingdom) (Haran); Sven Winter (University of Vienna, Vienna, Austria), Ariel Friedman (Tel Aviv University, Tel Aviv, Israel), Brigitte Gottsberger (University of Vienna, Vienna, Austria) 
(Letsch); Asela Wijeratne (Arkansas State University, Jonesboro, AR, USA) (McKenna); Athena Lam (Bavarian State Collection of Zoology, Munich, Germany), Alex Riedel (State Museum of Natural History Karlsruhe, Germany), Michael Balke (Bavarian State Collection of Zoology, Munich, Germany); Flavia Mendonca de Sousa, Sarah Pangburn, Sara Eslami, Mary Kate Dornon, and Anna Hakes (all Wellesley College, Wellesley, MA, USA) (Andrea Sequeira); Peter Stüben (Curculio-Institute, Mönchengladbach, Germany) (André Schütte); Karen F. Armstrong (Lincoln University, New Zealand), Barbara I. P. Barratt (AgResearch, NZ), Rob Cruickshank (Christchurch City Libraries, NZ) and Craig Phillips (AgResearch, NZ) (Samuel D. J. Brown). USDA is an equal opportunity employer.

Conflicts of Interest: The authors declare no conflict of interest. The funding sponsors had no role in the design of the study; in the collection, analyses, or interpretation of data; in the writing of the manuscript and in the decision to publish the results.

\section{References}

1. McKenna, D.D. Molecular phylogenetics and evolution of Coleoptera. In Handbook of Zoology, Volume IV: Arthropoda: Insecta. Part 38 Coleoptera, Beetles Volume 3: Morphology and Systematics (Phytophaga); Leschen, R.A.B., Beutel, R.G., Eds.; Walter de Gruyter: Berlin, Germany, 2014; pp. 1-10, ISBN 978-3-11-027370-0.

2. Haddad, S.; McKenna, D.D. Phylogeny and evolution of superfamily Chrysomeloidea (Coleoptera: Cucujiformia). Syst. Entomol. 2016, 41, 697-716. [CrossRef]

3. Robertson, J.A.; Slipinski, A.; Moulton, M.; Shockley, F.W.; Giorgi, A.; Lord, N.P.; McKenna, D.D.; Tomaszewska, W.; Forrester, J.; Miller, K.B.; et al. Phylogeny and classification of Cucujoidea and the recognition of a new superfamily Coccinelloidea (Coleoptera: Cucujiformia). Syst. Entomol. 2015, 40, 745-778. [CrossRef]

4. McKenna, D.D.; Wild, A.L.; Kanda, K.; Bellamy, C.L.; Beutel, R.G.; Caterino, M.S.; Farnum, C.W.; Hawks, D.C.; Ivie, M.A.; Jameson, M.L.; et al. The beetle tree of life reveals that Coleoptera survived end-Permian mass extinction to diversify during the Cretaceous terrestrial revolution. Syst. Entomol. 2015, 40, 835-880. [CrossRef]

5. McKenna, D.D. Molecular Systematics of Coleoptera; Leschen, R.A.B., Beutel, R.G., Eds.; Walter de Gruyter: Berlin, Germany, 2016; Volume 1, pp. 23-34.

6. Sereno, P.C. Logical basis for morphological characters in phylogenetics. Cladistics 2007, 23, $565-587$. [CrossRef]

7. Franz, N.M. Anatomy of a cladistic analysis. Cladistics 2014, 30, 294-321. [CrossRef]

8. Rieppel, O. The performance of morphological characters in broad-scale phylogenetic analyses. Biol. J. Linn. Soc. 2007, 92, 297-308. [CrossRef]

9. Davis, S.R. The weevil rostrum (Coleoptera: Curculionoidea): Internal structure and evolutionary trends. Bull. Am. Mus. Natl. Hist. 2017, 416, 1-76. [CrossRef]

10. McKenna, D.D.; Sequeira, A.S.; Marvaldi, A.E.; Farrell, B.D. Temporal lags and overlap in the diversification of weevils and flowering plants. Proc. Natl. Acad. Sci. USA 2009, 106, 7083-7088. [CrossRef] [PubMed]

11. McKenna, D.D. Temporal lags and overlap in the diversification of weevils and flowering plants: Recent advances and prospects for additional resolution. Am. Entomol. 2011, 57, 54-55. [CrossRef]

12. Shin, S.; Clarke, D.J.; Lemmon, A.R.; Lemmon, E.M.; Aitken, A.L.; Haddad, S.; Farrell, B.D.; Marvaldi, A.E.; Oberprieler, R.G.; McKenna, D.D. Phylogenomic data yield new and robust insights into the phylogeny and evolution of weevils. Mol. Biol. Evol. 2018, 35, 823-836. [CrossRef] [PubMed]

13. Marvaldi, A.E. Higher level phylogeny of Curculionidae (Coleoptera: Curculionoidea) based mainly on larval characters, with special reference to broad-nosed weevils. Cladistics 1997, 13, 285-312. [CrossRef]

14. Marvaldi, A.E.; Sequeira, A.S.; O’Brien, C.W.; Farrell, B.D. Molecular and morphological phylogenetics of weevils (Coleoptera, Curculionoidea): Do niche shifts accompany diversification? Syst. Biol. 2002, 51, 761-785. [CrossRef] [PubMed]

15. May, B.M. Fauna of New Zealand, 28. Larvae of Curculionoidea (Insecta: Coleoptera): A Systematic Overview; Manaaki Whenua Press: Lincoln, New Zealand, 1993; 226p.

16. Lawrence, J.F.; Beutel, R.G.; Leschen, R.A.B.; Slipinski, A. Arthropoda: Insecta. Part 38 Coleoptera, Beetles. Morphology and Systematics (Phytophaga). In Handbook of Zoology Glossary of Morphological Terms; Leschen, R.A.B., Beutel, R.G., Eds.; Walter de Gruyter: Berlin, Germany, 2010; Volume 2.4, pp. 9-20. 
17. Davis, S.R. Developmental Genetics in a Complex Adaptive Structure, the Weevil Rostrum. bioRxiv 2018. [CrossRef]

18. Nobuchi, A. Studies on Scolytidae (Coleoptera) XXI. Three new genera and species from Japan. Kontyû 1981, $49,12-18$.

19. Hulcr, J.; Atkinson, T.H.; Cognato, A.I.; Jordal, B.H.; McKenna, D.D. Morphology, Taxonomy, and Phylogenetics of Bark Beetles. In Bark Beetles: Biology and Ecology of Native and Invasive Species; Vega, F., Hofstetter, R., Eds.; Elsevier: Orlando, FL, USA, 2014; pp. 41-81.

20. Jordal, B.H.; Sequeira, A.S.; Cognato, A.I. The age and phylogeny of wood boring weevils and the origin of subsociality. Mol. Phylogenet. Evol. 2011, 59, 708-724. [CrossRef] [PubMed]

21. Jordal, B.H.; Kaidel, J. Phylogenetic analysis of Micracidini bark beetles (Coleoptera: Curculionidae) demonstrates a single trans-Atlantic disjunction and inclusion of Cactopinus in the New World clade. Can. Entomol. 2017, 149, 8-25. [CrossRef]

22. Pistone, D.; Gohli, J.; Jordal, B.H. Molecular phylogeny of bark and ambrosia beetles (Curculionidae: Scolytinae) based on 18 molecular markers. Syst. Entomol. 2018, 43, 387-406. [CrossRef]

23. Johnson, A.J.; McKenna, D.D.; Jordal, B.H.; Cognato, A.I.; Smith-Cognato, S.M.; Lemmon, A.R.; Lemmon, E.L.; Hulcr, J. Phylogenomics reveals repeated evolutionary origins of mating systems and fungus farming in bark beetles. Mol. Phylogenet. Evol. 2018, in press. [CrossRef] [PubMed]

24. Zhang, G.; Basharat, U.; Matzke, N.; Franz, N.M. Model selection in statistical historical biogeography of Neotropical insects-The Exophthalmus genus complex (Curculionidae: Entiminae). Mol. Phyologenet. Evol. 2017, 109, 226-239. [CrossRef] [PubMed]

25. Buchner, P. Endosymbiosis of Animals with Plant Micro-Organisms; Interscience Publishers: New York, NY, USA, 1965; 160p.

26. Zhang, G.; Browne, P.; Zhen, G.; Johnston, A.; Cadillo-Quiroz, H.; Franz, N. Endosymbiont diversity and evolution across the weevil tree of life. bioRxiv 2017. [CrossRef]

27. Gries, C.; Gilbert, E.E.; Franz, N.M. Symbiota-A virtual platform for creating voucher-based biodiversity information communities. Biodivers. Data J. 2014, 2, e1114. [CrossRef] [PubMed]

28. Anderson, W.H. Larvae of some genera of Calendrinae (=Rhynchophorinae) and Stromboscerinae. Ann. Entomol. Soc. Am. 1948, 41, 413-437. [CrossRef]

29. Franz, N.M.; Pier, N.M.; Reeder, D.M.; Chen, M.; Yu, S.; Kianmajd, P.; Bowers, S.; Ludäscher, B. Two influential primate classifications logically aligned. Syst. Biol. 2016, 6, 561-582. [CrossRef] [PubMed]

30. Franz, N.M.; Musher, L.J.; Brown, J.W.; Yu, S.; Ludäscher, B. Verbalizing phylogenomic conflict: Representation of node congruence across competing reconstructions of the neoavian explosion. bioRxiv 2017. [CrossRef]

31. Oberprieler, R.G.; Anderson, R.S.; Marvaldi, A.E. 3. Curculionoidea Latreille, 1802: Introduction, Phylogeny. In Handbook of Zoology: Arthropoda: Insecta. Part 38. Coleoptera, Beetles Volume 3: Morphology and Systematics (Phytophaga); Leschen, R.A.B., Beutel, R.G., Eds.; Walter de Gruyter: Berlin, Germany, 2014; Volume 3, pp. 285-300, ISBN 978-3-11-027370-0.

32. McKenna, D.D.; Farrell, B.D.; Caterino, M.S.; Farnum, C.W.; Hawks, D.C.; Maddison, D.R.; Seago, A.E.; Short, A.E.Z.; Newton, A.F.; Thayer, M.K. Phylogeny and evolution of Staphyliniformia and Scarabaeiformia (rove and scarab beetles): Forest litter as a stepping-stone for diversification of non-phytophagous beetles. Syst. Entom. 2014, 40, 35-60. [CrossRef]

33. Morimoto, K. Comparative morphology and phylogeny of the superfamily Curculionoidea of Japan. J. Fac. Agric. Kyushu Univ. 1962, 11, 331-373.

34. Kuschel, G. Entomology of the Aucklands and other islands south of New Zealand: Coleoptera: Curculionidae. Pac. Insects Monogr. 1971, 27, 225-259.

35. Thompson, RT. Observations on the morphology and classification of weevils (Coleoptera, Curculionoidea) with a key to major groups. J. Nat. Hist. 1992, 26, 835-891. [CrossRef]

36. Zimmerman, E.C. Australian Weevils (Coleoptera: Curculionoidea). III. Nanophyidae, Rhynchophoridae, Erirhinidae, Curculionidae: Amycterinae, Literature Consulted; CSIRO: Melbourne, Australia, 1994.

37. Zimmerman, E.C. Australian Weevils (Coleoptera: Curculionoidea). I. Orthoceri, Anthribidae to Attelabidae; CSIRO: Melbourne, Australia, 1994.

38. Alonso-Zarazaga, M.A. On terminology in Curculionoidea (Coleoptera). Bol. Soc. Entomól. Aragon. 2007, 40,210 
39. Kuschel, G. A phylogenetic classification of Curculionoidea to families and subfamilies. Mem. Entomol. Soc. Wash. 1995, 14, 5-33.

40. Marvaldi, A.E.; Morrone, J.J. Phylogenetic systematics of weevils (Coleoptera: Curculionoidea): A reappraisal based on larval and adult morphology. Insect Syst. Evol. 2000, 31, 43-58. [CrossRef]

41. Morimoto, K.; Kojima, H. New taxa. Curculionoidea: General introduction and Curculionidae: Entiminae (part 1) Phyllobiini, Polydrusini and Cyphicerini (Coleoptera). In The Insects of Japan; Morimoto, K., Kojima, H., Eds.; Fukuoka: Touka Shobo, Japan, 2006; Volume 3, pp. 1-406.

42. Hundsdoerfer, A.K.; Rheinheimer, J.; Wink, M. Towards the phylogeny of the Curculionoidea (Coleoptera): Reconstructions from mitochondrial and nuclear ribosomal DNA sequences. Zool. Anz. J. Comp. Zool. 2009, 248, 9-31. [CrossRef]

43. Haran, J.; Timmermans, M.J.T.N.; Vogler, A.P. Mitogenome sequences stabilize the phylogenetics of weevils (Curculionoidea) and establish the monophyly of larval ectophagy. Mol. Phylogenet. Evol. 2013, 67, 15-166. [CrossRef] [PubMed]

44. Gillett, C.P.D.T.; Crampton-Platt, A.; Timmermans, M.J.T.N.; Jordal, B.H.; Emerson, B.C.; Vogler, A.P. Bulk de novo mitogenome assembly from pooled total DNA elucidates the phylogeny of weevils (Coleoptera: Curculionoidea). Mol. Biol. Evol. 2014, 31, 2223-2237. [CrossRef] [PubMed]

45. Haddad, S.; Shin, S.; Lemmon, A.R.; Moriarty Lemmon, E.; Svacha, P.; Farrell, B.D.; Ślipiński, A.; Windsor, D.; McKenna, D.D. Anchored hybrid enrichment provides new insights into the phylogeny and evolution of longhorned beetles (Cerambycidae). Syst. Entomol. 2018, 43, 68-89. [CrossRef]

46. Arnoldi, L.V. Mesozoic Coleoptera. Eobelidae; Arnoldi, L.V., Zherikhin, V.V., Eds.; Nauka: Moscow, Russia, 1977; pp. 144-176.

47. Gratshev, V.G.; Zherikhin, V.V. A revision of the Late Jurassic nemonychid weevil genera Distenorrhinus and Procurculio (Insecta, Coleoptera, Nemonychidae). Paleontol. Zhurnal 1995, 2, 83-84.

48. Gratshev, V.G.; Zherikhin, V.V. A revision of the nemonychid weevil subfamily Brethorrhininae [sic] (Insecta, Coleoptera, Nemonychidae). Paleontol. J. 1995, 29, 112-127.

49. Davis, S.R.; Engel, M.S.; Legalov, A.; Ren, D. Weevils of the Yixian Formation, China (Coleoptera: Curculionoidea): Phylogenetic considerations and comparison with other Mesozoic faunas. J. Syst. Palaeontol. 2013, 11, 399-429. [CrossRef]

50. Santos, M.F.A.; Mermudes, J.R.M.; Fonseca, V.M.M. Description of a new genus and species of Belinae (Belidae, Curculionoidea, Coleoptera) from the Santana Formation (Crato member, Lower Cretaceous) of the Araripe basin, northeastern Brazil. In Paleontology: Life Scenarios, v.1; Carvalho, I.S., Cassab, R.C.T., Schwanke, C., Eds.; Interscience: Rio de Janeiro, Brazil, 2007; pp. 449-455.

51. Santos, M.F.A.; Mermudes, J.R.M.; Fonseca, V.M.M. A specimen of Curculioninae (Curculionidae, Coleoptera) from the Lower Cretaceous, Araripe Basin, north-eastern Brazil. Palaeontology 2011, 54, 807-814. [CrossRef]

52. Anderson, R.S.; Oberprieler, R.G.; Marvaldi, A.E. 3.1 Nemonychidae Bedel, 1882. In Handbook of Zoology, Volume IV: Arthropoda: Insecta. Part 38 Coleoptera, Beetles Volume 3: Morphology and Systematics (Phytophaga); Leschen, R.A.B., Beutel, R.G., Eds.; Walter de Gruyter: Berlin, Germany, 2014; Volume 3.4, pp. 301-309.

53. Caldara, R.; Franz, N.M.; Oberprieler, R.G. Curculionidae Latreille, 1802. 3.7.19 Curculionidae Latreille, 1802. In Handbook of Zoology, Volume IV: Arthropoda: Insecta. Part 38 Coleoptera, Beetles Volume 3: Morphology and Systematics (Phytophaga); Leschen, R.A.B., Beutel, R.G., Eds.; Walter de Gruyter: Berlin, Germany, 2014; pp. 589-628.

54. Bondar, G.G. Notas Entomológicas da Bahia. XIII. Rev. Entomol. 1943, 14, 337-388.

55. Franz, N.M.; Valente, R.M. Evolutionary trends in derelomine flower weevils (Coleoptera: Curculionidae): From associations to homology. Invertebr. Syst. 2005, 19, 499-530. [CrossRef]

56. De Medeiros, B.A.S.; Núñez-Avellaneda, L.A. Three new species of Anchylorhynchus Schoenherr, 1836 from Colombia (Coleoptera: Curculionidae; Curculioninae; Acalyptini). Zootaxa 2013, 3636, 394-400. [CrossRef] [PubMed]

57. Valente, R.M.; de Medeiros, B.A.S. A new species of Anchylorhynchus Schoenherr (Coleoptera: Curculionidae) from the Amazon, with a record of a new host palm for the genus. Zootaxa 2013, 3709, 394-400. [CrossRef]

58. Silberbauer-Gottsberger, I.; Vanin, S.A.; Gottsberger, G. Interactions of the Cerrado Palms Butia paraguayensis and Syagrus petraea with Parasitic and Pollinating Insects. Sociobiology 2013, 60, 306-316. [CrossRef] 
59. Valente, R.M.; da Silva, P.A.L. The first Amazonian species of Andranthobius Kuschel (Coleoptera: Curculionidae), with records of new host palms for the genus. Zootaxa 2014, 3786, 458-468. [CrossRef] [PubMed]

60. Guerrero-Olaya, N.Y.; Núñez-Avellaneda, L.A. Ecología de la polinización de Syagrus smithii (Arecaceae), una palma cantarofila de la Amazonia Colombiana. Rev. Peru. Biol. 2017, 24, 43-54. [CrossRef]

61. Nuñez Avellaneda, L.A.; Carreño, J.I. Polinización por abejas en Syagrus orinocensis (Arecaceae) en la Orinoquia colombiana. Acta Biol. Colomb. 2017, 22, 221-233. [CrossRef]

62. Meerow, A.W.; Noblick, L.R.; Salas-Leiva, D.E.; Sanchez, V.; Francisco-Ortega, J.; Jestrow, B.; Nakamura, K. Phylogeny and historical biogeography of the cocosoid palms (Areaceae, Arecoideae, Cocoseae) inferred from sequences of six WRKY gene family loci. Cladistics 2015, 31, 509-534. [CrossRef]

63. Noblick, L.R. A revision of the genus Syagrus (Arecaceae). Phytotaxa 2017, 294, 1. [CrossRef]

64. Sakai, S. A review of brood-site pollination mutualism: Plants providing breeding sites for their pollinators. J. Plant Res. 2002, 115, 161-168. [CrossRef] [PubMed]

65. Hembry, D.H.; Althoff, D.M. Diversification and coevolution in brood pollination mutualisms: Windows into the role of biotic interactions in generating biological diversity. Am. J. Bot. 2016, 103, 1783-1792. [CrossRef] [PubMed]

66. Núñez-Avellaneda, L.A.; Rojas-Robles, R. Biología Reproductiva y Ecología de la Polinización de la Palma Milpesos Oenocarpus bataua en los Andes Colombianos. Caldasia 2008, 30, 101-125.

67. De Medeiros, B.A.S.; Bená, D.C.; Vanin, S.A. Curculio Curculis lupus: Biology, behavior and morphology of immatures of the cannibal weevil Anchylorhynchus eriospathae G. G. Bondar. PeerJ 1943, 2, 1-26.

68. Núñez-Avellaneda, L.A.; Isaza, C.; Galeano, G. Ecología de la polimización de tres especies de Oenocarpus (Arecaceae) simpátricas en la Amazonia colombiana. Rev. Biol. Trop. 2015, 63, 35-55. [CrossRef]

69. Peterson, B.K.; Weber, J.N.; Kay, E.H.; Fisher, H.S.; Hoekstra, H.E. Double Digest RADseq: An Inexpensive Method for De Novo SNP Discovery and Genotyping in Model and Non-Model Species. PLoS ONE 2012, 7, e37135. [CrossRef] [PubMed]

70. Peñalba, J.V.; Smith, L.L.; Tonione, M.A.; Sass, C.; Hykin, S.M.; Skipwith, P.L.; McGuire, J.A.; Bowie, R.C.K.; Moritz, C. Sequence capture using PCR-generated probes: A cost-effective method of targeted high-throughput sequencing for nonmodel organisms. Mol. Ecol. Res. 2014, 14, 1000-1010. [CrossRef] [PubMed]

71. De Medeiros, B.A.S.; Farrell, B.D. Whole-genome amplification in double-digest RAD-seq results in adequate libraries but fewer sequenced loci. Peer] 2018, 6, e5089. [CrossRef]

72. Anderson, R.S. An evolutionary perspective on diversity in Curculionoidea. In Biology and Phylogeny of Curculionoidea, Proceedings of the XVIII International Congress of Entomology, Vancouver, BC, Canada, 3-9 July 1988; Anderson, R.S., Lyal, C.H.C., Eds.; Entomological Society of Washington: Washington, DC, USA, 1988; Volume 14, pp. 103-114.

73. Becerra, J.X.; Venable, D.L. Macroevolution of insect-plant associations: The relevance of host biogeography to host affiliation. Proc. Natl. Acad. Sci. USA 1999, 96, 12626-12631. [CrossRef] [PubMed]

74. Anderson, R.S. Weevils and plants: Phylogenetic versus ecological mediation of evolution of host plant associations in Curculionidae (Curculioninae). Mem. Entomol. Soc. Can. 1993, 165, 197-232. [CrossRef]

75. Franz, N. Analysing the history of the derelomine flower weevil-Carludovica association (Coleoptera: Curculionidae; Cyclanthaceae). Biol. J. Linn. Soc. 2004, 81, 483-517. [CrossRef]

76. Anderson, R.S.; Marvaldi, A.E. Finding unexpected beetles in odd places: Archicorynus kuscheli Anderson and Marvaldi, a new genus and species representing a new tribe, Archicorynini, of Oxycoryninae (Coleoptera: Belidae) from Nicaragua. Coleopt. Bull. 2013, 67, 61-71. [CrossRef]

77. Arensburger, P.; Buckley, T.R.; Simon, C.; Moulds, M.; Holsinger, K. Biogeography and phylogeny of the New Zealand cicada genera (Hemiptera: Cicadidae) based on nuclear and mitochondrial DNA data. J. Biogeogr. 2004, 31, 557-569. [CrossRef]

78. Boyer, S.L.; Giribet, G. Welcome back New Zealand: Regional biogeography and Gondwanan origin of three endemic genera of mite harvestmen (Arachnida, Opiliones, Cyphophthalmi). J. Biogeogr. 2009, 36, 1084-1099. [CrossRef]

79. Riedel, A.; Tänzler, R.; Pons, J.; Suhardjono, Y.R.; Balke, M. Large-scale molecular phylogeny of Cryptorhynchinae (Coleoptera, Curculionidae) from multiple genes suggests American origin and later Australian radiation. Syst. Entomol. 2016, 41, 492-503. [CrossRef] 
80. Holloway, B.A. Anthribidae (Insecta: Coleoptera); Department of Science, Industrial Research: Lincoln, NE, USA, 1984; Volume 3, p. 269.

81. Kuschel, G. Nemonychidae, Belidae, Brentidae (Insecta: Coleoptera: Curculionoidea); Manaaki Whenua Press: Lincoln, NE, USA, 2003; 100p.

82. Lyal, C.H.C. Cryptorhynchinae (Insecta: Coleoptera: Curculionidae); Landcare Research: Lincoln, NE, USA, 1993; Volume 29, 305p.

83. Brown, S.D.J. Austromonticola, a new genus of broad-nosed weevil (Coleoptera: Curculionidae: Entiminae) from montane areas of New Zealand. ZooKeys 2017, 707, 73-130. [CrossRef] [PubMed]

84. Leschen, R.A.B.; Lawrence, J.F.; Kuschel, G.; Thorpe, S.; Wang, Q. Coleoptera genera of New Zealand. N. Z. Entomol. 2003, 26, 15-28. [CrossRef]

85. Macfarlane, R.P.; Maddison, P.A.; Andrew, I.G.; Berry, J.A.; Johns, P.M.; Hoare, R.J.B.; Lariviere, M.C.; Greenslade, P.; Henderson, R.C.; Smithers, C.; et al. Chapter Nine. Phylum Arthropoda; subphylum Hexapoda; Protura, springtails, Diplura and insects. In New Zealand Inventory of Biodiversity, Kingdom Animalia, Chaetognatha, Ecdysozoa, Ichnofossils; Gordon, D.P., Ed.; Canterbury University Press: Canterbury, Australia, 2011; Volume 2, pp. 233-467.

86. Mazur, M.A. First record of the tribe Eugnomini Lacordaire, 1863 (Coleoptera: Curculionidae) from Fiji with description of Pactola fiji sp. n. Zootaxa 2012, 3517, 63-70.

87. Mazur, M.A. Review of the New Caledonian species of the genus Pactola Pascoe, 1876 (Coleoptera: Curculionidae: Eugnomini), with description of two new species. Zootaxa 2014, 3814, 202-220. [CrossRef] [PubMed]

88. Kaulfuss, U.; Brown, S.D.J.; Henderson, I.; Szwedo, J.; Lee, D. First insects from the Manuherikia Group, early Miocene, New Zealand. J. R. Soc. N. Z. 2018, 1-14. [CrossRef]

89. Grebennikov, V.V. First Alaocybites weevil (Insecta: Coleoptera: Curculionoidea) from the Eastern Palaearctic: A new micropthalmic species and generic relationships. Arthropod Syst. Phyl. 2010, 68, 331-365.

90. Painting, C.J.; Holwell, G.I. Exaggerated trait allometry, compensation and trade-offs in the New Zealand giraffe weevil (Lasiorhynchus barbicornis). PLoS ONE 2013, 8, e82467. [CrossRef] [PubMed]

91. Painting, C.J.; Holwell, G.I. Temporal variation in body size and weapon allometry in the New Zealand giraffe weevil. Ecol. Entomol. 2015, 40, 486-489. [CrossRef]

92. Johst, K.; Schöps, K. Persistence and conservation of a consumer-resource metapopulation with local overexploitation of resources. Biol. Conserv. 2003, 109, 57-65. [CrossRef]

93. Lanteri, A.A.; Normark, B.B. Parthenogenesis in the tribe Naupactini (Coleoptera: Curculionidae). Ann. Entomol. Soc. Am. 1995, 88, 722-731. [CrossRef]

94. Rodriguero, M.S.; Confalonieri, V.A.; Guedes, J.V.C.; Lanteri, A.A. Wolbachia infection in the tribe Naupactini (Coleoptera, Curculionidae): Association between thelytokous parthenogenesis and infection status. Insect Mol. Biol. 2010, 19, 599-705.

95. Rodriguero, M.S.; Aquino, D.A.; Loiácono, M.S.; Elías Costa, A.J.; Confalonieri, V.A.; Lanteri, A.A. Parasitoidism of the "Fuller's rose weevil" Naupactus cervinus by Microctonus sp. larvae. BioControl 2014, 59, 547-556. [CrossRef]

96. Rodriguero, M.S.; Wirth, S.A.; Alberghina, J.S.; Lanteri, A.A.; Confalonieri, V.A. A tale of swinger insects: Signatures of past sexuality between divergent lineages of a parthenogenetic weevil revealed by ribosomal intraindividual variation. PLoS ONE 2018, 13, e0195551. [CrossRef] [PubMed]

97. Timmermans, M.J.T.N.; Dodsworth, S.; Culverwell, C.L.; Bocak, L.; Ahrens, D.; Littlewood, D.T.J.; Pons, J.; Vogler, A.P. Why barcode? Highthroughput multiplex sequencing of mitochondrial genomes for molecular systematics. Nucleic Acids Res. 2010, 38, 1-14. [CrossRef] [PubMed]

98. Timmermans, M.J.T.N.; Barton, C.; Haran, J.; Ahrens, D.; Culverwell, L.; Ollikainen, A.; Dodsworth, S.; Foster, P.G.; Bocak, L.; Vogler, A.P. Family-level sampling of mitochondrial genomes in Coleoptera: Compositional heterogeneity and phylogenetics. Gen. Biol. Evol. 2016, 8, 161-175. [CrossRef] [PubMed]

99. Timmermans, M.J.T.N.; Vogler, A.P. Phylogenetically informative rearrangements in mitochondrial genomes of Coleoptera, and monophyly of aquatic elateriform beetles (Dryopoidea). Mol. Phylogenet. Evol. 2012, 63, 299-304. [CrossRef] [PubMed]

100. Alonso-Zarazaga, M.A. Revision of the supraspecific taxa in the Palaearctic Apionidae Schoenherr, 1823 (Coleoptera, Curculionoidea). 2. Subfamily Apioninae Schoenherr, 1823: Introduction, keys and descriptions. Graellsia 1990, 46, 19-156. 
101. Wanat, M. Genera of Australo-Pacific Rhadinocybinae and Myrmacicelinae: With Biogeography of the Apionidae (Coleoptera: Curculionoidea) and Phylogeny of the Brentidae (s. lato); Mantis: Oslztyn, Poland, 2001; 432p, ISBN 978-8391433614.

102. Letsch, H.; Gottsberger, B.; Metzl, C.; Astrin, J.J.; Friedman, A.L.L.; McKenna, D.D.; Fiedler, K. Climate and host plant associations shaped the evolution of weevils (Curculionidae: Ceutorhynchinae) throughout the Cenozoic. Evolution 2018, in press. [CrossRef]

103. Faust, J. Stellung und neue Arten der asiatischen Rüsselkäfergattung Catapionus. Deutsch. Entomol. Z. 1883, 27, 81-98.

104. Niehuis, O.; Hartig, G.; Grath, S.; Pohl, H.; Lehmann, J.; Tafer, H.; Donath, A.; Krauss, V.; Eisenhardt, C.; Hertel, J.; et al. Genomic and morphological evidence converge to resolve the enigma of Strepsiptera. Curr. Biol. 2012, 23, 1388. [CrossRef]

105. Misof, B.; Liu, S.; Meusemann, K.; Peters, R.S.; Donath, A.; Mayer, C.; Frandsen, R.B.; Ware, J.; Flouri, T.; Beutel, R.G.; et al. Phylogenomics Resolves the Timing and Pattern of Insect Evolution. Science 2014, 346, 763-767. [CrossRef] [PubMed]

106. Kjer, K.H.; Aspock, U.; Aspock, R.G.; Beutel, A.; Blanke, A.; Donath, T.; Flouri, P.; Frandsen, L.; Jermiin, P.; Kapli, A.; et al. Response to comment on 'Phylogenomics resolves the timing and pattern of insect evolution'. Science 2015, 349, 487-488. [CrossRef] [PubMed]

107. McKenna, D.D. Beetle systematics in the 21st Century: Prospects and progress from studies of genes and genomes. Curr. Opin. Insect Sci. 2018, 24, 76-82. [CrossRef] [PubMed]

108. Scully, E.D.; Geib, S.M.; Carlson, J.E.; Tien, M.; McKenna, D.D.; Hoover, K. Functional genomics and microbiome profiling of the Asian longhorned beetle (Anoplophora glabripennis) reveal new insights into the digestive physiology and nutritional ecology of wood-feeding beetles. BMC Genom. 2014, 15, 1096. [CrossRef] [PubMed]

109. McKenna, D.D.; Scully, E.D.; Pauchet, Y.; Hoover, K.; Kirsch, R.; Geib, S.M.; Mitchell, R.F.; Waterhouse, R.M.; Ahn, S.; Arsala, D.; et al. Genome of the Asian longhorned beetle (Anoplophora glabripennis), a globally significant invasive species, reveals key functional and evolutionary innovations at the beetle-plant interface. Genome Biol. 2016, 17, 227. [CrossRef] [PubMed]

110. McKenna, D.D. Towards a temporal framework for "Inordinate Fondness": Reconstructing the macroevolutionary history of beetles (Coleoptera). Entomol. Am. 2011, 117, 28-36. [CrossRef]

111. Sharkey, C.R.; Fujimoto, M.S.; Lord, N.P.; Shin, S.; McKenna, D.D.; Suvorov, A.; Martin, G.J.; Bybee, S.M. Beetle UV opsin gene duplications restore the lost short wave insect opsin class. Sci. Rep. 2017, 7, 8. [CrossRef] [PubMed]

112. Mitchell, R.F.; Hall, L.P.; Reagel, P.F.; McKenna, D.D.; Baker, T.C.; Hildebrand, J.G. Odorant receptors and antennal lobe morphology offer a new approach to understanding the olfactory biology of the Asian longhorned beetle (Anoplophora glabripennis). J. Comp. Physiol. A 2017, 203, 99-109. [CrossRef] [PubMed]

113. Faircloth, B.C.; McCormack, J.E.; Crawford, N.G.; Harvey, M.G.; Brumfield, R.T.; Glenn, T.C. Ultraconserved Elements Anchor Thousands of Genetic Markers Spanning Multiple Evolutionary Timescales. Syst. Biol. 2012, 61, 717-726. [CrossRef] [PubMed]

114. Riedel, A. Revision of the genus Penthoscapha Heller (Coleoptera, Curculionoidea, Entiminae, Eupholini) with notes on the genera of Eupholini from New Guinea. Zootaxa 2009, 2224, 1-29. [CrossRef]

115. Gressitt, J.L.; Sedlacek, J.; Szent-Ivany, J.J.H. Flora and Fauna on Backs of Large Papuan Moss-Forest Weevils. Science 1965, 80, 150. [CrossRef] [PubMed]

116. Stamatakis, A. RAxML version 8: A tool for phylogenetic analysis and post-analysis of large phylogenies. Bioinformatics 2014, 30, 1312-1313. [CrossRef] [PubMed]

117. Chifman, J.; Kubatko, L. Quartet Inference from SNP Data under the Coalescent Model. Bioinformatics 2014, 30, 3317-3324. [CrossRef] [PubMed]

118. Zhang, C.; Sayyari, E.; Mirarab, S. ASTRAL-III: Increased Scalability and Impacts of Contracting Low Support Branches. In Lecture Notes in Computer Science. Comparative Genomics, RECOMB-CG; Meidanis, J., Nakhleh, L., Eds.; Springer: Cham, Switzerland, 2017; Volume 1, pp. 53-75.

119. Van Dam, M.H.; Lam, A.W.; Sagata, K.; Gewa, B.; Laufa, R.; Balke, A. Ultraconserved elements (UCEs) resolve the phylogeny of Australasian smurf-weevils. PLOS ONE 2017, 12, e0188044. [CrossRef] [PubMed]

120. Gohli, J.; Kirkendall, L.R.; Smith, S.M.; Cognato, A.I.; Hulcr, J.; Jordal, B.H. Biological factors contributing to bark and ambrosia beetle species diversification. Evolution 2017, 71, 1258-1272. [CrossRef] [PubMed] 
121. Kambestad, M.; Kirkendall, L.R.; Knutsen, I.L.; Jordal, B.H. Cryptic and pseudo-cryptic diversity in the world's most common bark beetle-Hypothenemus eruditus. Org. Divers. Evol. 2017, 17, 633-652. [CrossRef]

122. Gillespie, J.J.; Johnston, J.S.; Cannone, J.J.; Gutell, R.R. Characteristics of the Nuclear (18S, $5.8 S, 28 S$ and 5S) and mitochondrial (12S and 16S) rRNA genes of Apis mellifera (Insecta: Hymenoptera): Structure, organization, and retrotransposable elements. Insect Mol. Biol. 2006, 15, 657-686. [CrossRef] [PubMed]

123. Marvaldi, A.E.; Duckett, C.N.; Kjer, K.; Gillespie, J. Structural alignment of $18 \mathrm{~S}$ and $28 \mathrm{~S}$ rDNA sequences provides insights into phylogeny of Phytophaga (Coleoptera: Curculionoidea and Chrysomeloidea). Zool. Scr. 2009, 38, 63-77. [CrossRef]

124. Marvaldi, A.E.; Lanteri, A.A.; del Río, M.G.; Oberprieler, R.G. 3.7.5 Entiminae Schoenherr, 1823. In Handbook of Zoology, Volume IV: Arthropoda: Insecta. Part 38 Coleoptera, Beetles Volume 3: Morphology and Systematics (Phytophaga); Leschen, R.A.B., Beutel, R.G., Eds.; Walter de Gruyter: Berlin, Germany, 2014; pp. 503-522.

125. Oberprieler, R.G. A reclassification of the weevil subfamily Cyclominae (Coleoptera: Curculionidae). Zootaxa 2010, 2515, 1-35.

126. Oberprieler, R.G. 3.7.4 Cyclominae Schoenherr, 1826. In Handbook of Zoology, Volume IV: Arthropoda: Insecta. Part 38 Coleoptera, Beetles Volume 3: Morphology and Systematics (Phytophaga); Leschen, R.A.B., Beutel, R.G., Eds.; Walter de Gruyter: Berlin, Germany, 2014; pp. 483-502, ISBN 978-3-11-027370-0.

127. Bouchard, P.; Bousquet, Y.; Davies, A.E.; Alonso-Zarazaga, M.A.; Lawrence, J.F.; Lyal, C.H.C.; Newton, A.F.; Reid, C.A.M.; Schmitt, M.; Ślipiński, S.A.; et al. Family-group names in Coleoptera (Insecta). ZooKeys 2011, 88, 972. [CrossRef] [PubMed]

128. Gunter, N.L.; Oberprieler, R.G.; Cameron, S.L. Molecular phylogenetics of Australian weevils (Coleoptera: Curculionoidea): Exploring relationships in a hyperdiverse lineage through comparison of independent analyses. Austral Entomol. 2015, 55, 217-233. [CrossRef]

129. Lyal, C.H.C.; King, T. Elytro-tergal stridulation in weevils (Insecta: Coleoptera: Curculionoidea). J. Nat. Hist. 1996, 30, 703-773. [CrossRef]

130. Lyal, C.H.C.; Douglas, D.; Hine, S.J. Morphology and systematic significance of sclerolepidia in the weevils (Coleoptera: Curculionoidea). Syst. Biodivers. 2006, 4, 203-241. [CrossRef]

131. Alonso-Zarazaga, M.A.; Lyal, C.H.C. A World Catalogue of Families and Genera of Curculionoidea (Insecta: Coleoptera) (Excepting Scolytidae and Platypodidae); Entomopraxis: Barcelona, Spain, 1999; 315p.

132. Oberprieler, R.G.; Marvaldi, A.E.; Anderson, R.S. Weevils, Weevils, Weevils Everywhere. Zootaxa 2007, $1668,491-520$.

133. Cigliano, M.M.; Pocco, M.E.; Pereira, H.L. Avances tecnológicos y sus aplicaciones en la cibertaxonomía. Rev. Soc. Entomol. Argic. 2014, 73, 3-15.

134. International Weevil Community Website. Available online: http://weevil.info/ (accessed on 20 April 2018).

135. Glossary of Weevil Characters. Available online: http://weevil.info/glossary-weevil-characters/ (accessed on 20 April 2018).

136. WTaxa: Electronic Catalogue of Weevil Names (Curculionoidea). Web Version 3.0, Database Version 18. Available online: http:/ / wtaxa.csic.es/ (accessed on 20 April 2018).

137. New Zealand Weevil Images. Available online: http://weevils.landcareresearch.co.nz/ (accessed on 20 April 2018).

138. Potential Invasive Weeds of the World. Available online: http:/ / www.piweevils.com/ (accessed on 20 April 2018).

139. Coleoptera Neotropical. Available online: http:/ / www.coleoptera-neotropical.org (accessed on 20 April 2018).

140. Symbiota Collections of Arthropods Network (SCAN). Available online: http://scan-bugs.org/portal/ (accessed on 20 April 2018).

141. Beetles and Coleopterists. Available online: http://www.zin.ru/ANIMALIA/Coleoptera/ (accessed on 20 April 2018).

142. Leschen, R.A.B.; Beutel, R.G. Handbook of Zoology, Vol. IV: Arthropoda: Insecta. Part 38 Coleoptera, Beetles, Volume 3: Morphology and Systematics (Phytophaga); Walter de Gruyter: Berlin, Germany, 2014; 675p, ISBN 978-3-11-027370-0.

143. Krahulcova, A.; Krahulec, F.; Kirschner, J. Introgressive hybridization between a native and an introduced species: Viola lutea subsp sudetica versus. V. tricolor. Folia Geobot. 1996, 31, 219. [CrossRef]

144. Engilis, A., Jr.; Pratt, T. Status and population trends of Hawaii's native waterbirds. Wilson Bull. 1993, 105, 142-158. 
145. Lanteri, A.A. Systematics, cladistics and biogeography of a new weevil genus, Galapaganus (Coleoptera: Curculionidae) from the Galápagos Islands, and Coasts of Ecuador and Perú. Trans. Am. Entomol. Soc. 1992, 118, 227-267.

146. Sequeira, A.S.; Lanteri, A.A.; Albelo, L.R.; Bhattacharya, S.; Sijapati, M. Colonization history, ecological shifts and diversification in the evolution of endemic Galapagos weevils. Mol. Ecol. 2008, 17, 1089-1107. [CrossRef] [PubMed]

147. Mok, H.F.; Stepien, C.C.; Kaczmarek, M.; Albelo, L.R.; Sequeira, A.S. Genetic status and timing of a weevil introduction to Santa Cruz Island, Galapagos. J. Hered. 2014, 105, 365-380. [CrossRef] [PubMed]

148. Sequeira, A.S.; Cheng, A.; Pangburn, S.; Troya, A. Where can introduced populations learn their tricks? Searching for the geographical source of a species introduction to the Galápagos archipelago. Conserv. Genet. 2017, 18, 1403-1422. [CrossRef]

149. Hey, J.; Nielsen, R. Multilocus methods for estimating population sizes, migration rates and divergence time, with applications to the divergence of Drosophila pseudoobscura and D. persimilis. Genetics 2004, 167, 747-760. [CrossRef] [PubMed]

150. Hey, J. Documentation for IMa2; Department of Genetics, Rutgers University: Piscataway, NJ, USA, 2011.

151. Hey, J. Using the IMfig Program; Department of Genetics, Rutgers University: Piscataway, NJ, USA, 2011.

152. Hedrick, P.W. Adaptive introgression in animals: Examples and comparison to new mutation and standing variation as sources of adaptive variation. Mol. Ecol. 2013, 22, 4606-4618. [CrossRef] [PubMed]

153. Daehler, C.C.; Strong, D.R. Hybridization between introduced smooth cordgrass (Spartina alterniflora; Poaceae) and native California cordgrass (S. foliosa) in San Francisco Bay, California, USA. Am. J. Bot. 1997, 84, 607-611. [CrossRef] [PubMed]

154. Fitzpatrick, B.M.; Johnson, J.R.; Kump, D.K.; Smith, J.J.; Voss, S.R.; Shaffer, H.B. Rapid spread of invasive genes into a threatened native species. Proc. Natl. Acad. Sci. USA 2010, 107, 3606-3610. [CrossRef] [PubMed]

155. Stüben, P.E.; Schütte, A. Silvacalles (s. str.) carlinavorus sp.n. from La Gomera (Canary Islands) (Coleoptera: Curculionidae: Cryptorhynchinae). Snudebiller 2014, 15, 1-8.

156. Stüben, P.E.; Schütte, A.; Astrin, J.J. Molecular phylogeny of the weevil genus Dichromacalles Stüben (Curculionidae: Cryptorhynchinae) and description of a new species. Zootaxa 2013, 3718, 101-127. [CrossRef] [PubMed]

157. Schütte, A.; Stüben, P.E. Molecular systematics and morphological identification of the cryptic species of the genus Acalles Schoenherr, 1825, with descriptions of new species (Coleoptera: Curculionidae: Cryptorhynchinae). Zootaxa 2015, 3915, 1-51. [CrossRef] [PubMed]

158. Germann, C.; Wolf, I.; Schütte, A. Echinodera (Ruteria) soumasi sp. n. from Greece (Coleoptera, Curculionidae). Mitteilungen Schweizerischen Entomologischen Gesellschaft 2015, 88, 285-293.

159. Haran, J.; Schütte, A.; Friedman, A.L. A review of Smicronyx Schoenherr (Coleoptera, Curculionidae) of Israel, with description of two new species. Zootaxa 2017, 4237, 17-40. [CrossRef] [PubMed]

160. Schütte, A.; Stüben, P.; Sprick, P. The Molecular Weevil Identification Project (Coleoptera: Curculionoidea), Part I-A contribution to Integrative Taxonomy and Phylogenetic Systematics. Snudebiller 2013, 14, 1-77.

161. Stüben, P.E.; Schütte, A.; Bayer, C.; Astrin, J.J. The Molecular Weevil Identification Project (Coleoptera: Curculionoidea), Part II-Towards an Integrative Taxonomy. Snudebiller 2015, 16, 1-294.

162. Brown, S.D.J. A revision of the New Zealand weevil genus Irenimus Pascoe, 1876 (Coleoptera: Curculionidae: Entiminae). Zootaxa 2017, 4263, 1-42. [CrossRef] [PubMed]

(c) 2018 by the authors. Licensee MDPI, Basel, Switzerland. This article is an open access article distributed under the terms and conditions of the Creative Commons Attribution (CC BY) license (http:/ / creativecommons.org/licenses/by/4.0/). 